\title{
Exclusio boni prolis i jego przyczyny. Doktryna i orzecznictwo Sądu Diecezjalnego w Tarnowie
}

W procesach o stwierdzenie nieważności małżeństwa, jakie toczyły się na przestrzeni lat w Sądzie Diecezjalnym w Tarnowie, wielokrotnie występował tytuł symulacji zgody małżeńskiej. Jest to sytuacja, w której przynajmniej jeden $\mathrm{z}$ kontrahentów w akcie zgody małżeńskiej pozytywnym aktem woli ${ }^{1}$ wyklucza albo samo małżeństwo, albo jakiś jego istotny element lub przymiot ${ }^{2}$. O ile w pierwszym przypadku mamy do czynienia $\mathrm{z}$ symulacją całkowitą, o tyle $\mathrm{w}$ dwóch pozostałych z simulatio partialis. Pośród różnych form symulacji częściowej szczególne miejsce zajmuje

\footnotetext{
1 W przypadku symulacji częściowej niezbędność pozytywnego aktu odrzucenia (intencji niezobowiązywania się) odróżnia ją od zwykłego błędu, o którym traktuje kan. 1099 K Pк. Por. Kodeks Prawa Kanonicznego. Komentarz. Powszechne i partykularne ustawodawstwo Kościoła katolickiego. Podstawowe akty polskiego prawa wyznaniowego, red. P. Majer, Kraków 2011, s. 824; M. Pastuszko, Positivus actus voluntatis excludens matrimonium, „Prawo Kanoniczne” 18 (1975) nr 1-2, s. 92-94.

2 KPK 1983 kan. $1101 \$$ 2: „Jeśli jednak jedna ze stron albo obydwie pozytywnym aktem woli wykluczyłyby samo małżeństwo lub jakiś istotny element małżeństwa, albo jakiś istotny przymiot, zawierają je nieważnie". Por. A. Stankiewicz, De iurisprudentia recentiore circa simulationem totalem et partialem (ad usum privatum), Roma 2004, s. 14: „Haec sane distinctio admitti solet non quidem ratione effectus, qui semper idem est seu nullitas consensus et matrimonii, sed ratione obiecti simulationis et conscientiae simulati actus". Por. także: G. Dzierżon, Niezdolność do zawarcia małżeństwa jako kategoria kanoniczna, Warszawa 2002, s. 244.
} 
exclusio boni prolis, będące przedmiotem niniejszej analizy ${ }^{3}$. Aktualnie istniejący kryzys rodziny oraz dotykający wielu sfer niż demograficzny stanowią dobrą okazję do opracowania tego zagadnienia z punktu widzenia prawa tak materialnego, jak i procesowego.

\section{Prawna natura wykluczenia dobra potomstwa}

Jak stwierdza kan. $1057 \$ 2 \mathrm{KPK}, \mathrm{w}$ akcie zgody małżeńskiej mężczyzna i kobieta wzajemnie się sobie oddają w celu stworzenia małżeństwa i realizacji jego celów. Przedmiotem tego przekazania jest także ich własna płciowość, która poprzez ukierunkowanie na potomstwo zmierza do budowania prawdziwej komunii - czyli jedności duchowo-cielesnej.

Gdy więc zabraknie tego wzajemnego przyjęcia i oddania się drugiej stronie, także w aspekcie prawa do potomstwa, brak wówczas prawdziwej zgody małżeńskiej. Naturalnie zachodzi różnica między pragnieniem potomstwa a prawem do potomstwa w sensie kanonicznym ${ }^{4}$. Dziecko dla swoich rodziców zawsze jest darem Boga i owocem ludzkiej miłości. Stąd Kościół w swoim nauczaniu wyklucza każdy niegodny środek, lokujący się najczęściej na płaszczyźnie technik zapłodnienia pozaustrojowego ${ }^{5}$. Dlatego nie powinno się mówić o prawie „do posiadania dziecka”, ale jedynie o prawie do płodnych aktów ludzkich. Tylko w takim znaczeniu należy rozumieć kanoniczne prawo do potomstwa. Do istoty małżeństwa nie jest konieczne narodzenie się potomstwa, lecz jedynie to, by akty małżeńskie były zdolne do jego zrodzenia. Prawo do tych aktów winno istnieć w samym momencie powzięcia zgody małżeńskiej, a nie w jakimś innym przyszłym czasie, określonym dowolnie przez chociażby jednego

3 W Sądzie Diecezjalnym w Tarnowie sprawy z tytułu exclusio boni prolis stanowią nieco ponad 2 proc. wszystkich spraw. Trzeba jednak dodać, że w zestawieniach wyraźnie uwidacznia się tendencja zwyżkowa.

4 Por. W. Góralski, Wykluczenie prawa do potomstwa w świetle nowszego orzecznictwa rotalnego, „Ius Matrimoniale” 2 (1997), s. 77.

5 Por. Paweł vi, Encyklika Humanae vitae, 25.07 .1968 r., [w:] Posoborowe dokumenty Kościoła katolickiego o małżeństwie i rodzinie, t. 1, Kraków 1999, s. 32-33; Kongregacja Nauki Wiary, Instrukcja Donum viatae [dalej: Dv], 22.02.1987 r., [w:] Posoborowe dokumenty Kościoła katolickiego o małżeństwie i rodzinie, t. 1, dz. cyt., 5; Konferencja Episkopatu Polski, O wyzwaniach bioetycznych, przed którymi stoi wspótczesny człowiek, 5.03.2013, „Gość Niedzielny" (dodatek), nr 15, rok xc, z 14.04.2013, s. 3-15; A. Katolo, Bioetyczne aspekty zapłodnienia in vitro, „Ethos” 14 (2001) nr 3, s. 208. 
z kontrahentów. Podczas gdy wyżej wspomniane prawo jest czymś pozytywnym, pragnienie potomstwa ma charakter subiektywny ${ }^{6}$.

Stąd aby małżeństwo mogło być uznane za nieważne z tytułu wykluczenia dobra potomstwa, nupturient powinien pozytywnym aktem woli, który może przybrać formę warunku lub paktu, wykluczyć bonum prolis przed wyrażeniem zgody małżeńskiej lub w chwili jej wyrażania. Treścią tego pozytywnego aktu woli nie jest efektywnie osiągnięte potomstwo, a nawet konkretny akt małżeński, lecz prawo do płodnego aktu małżeńskiego (ius ad coniugalem actum) lub prawo do potomstwa (ius ad prolem) - rozumianego jako konsekwencja tego aktu, albo też prawo do wychowania potomstwa (ius ad educationem $\mathrm{w}$ rozumieniu bonum physicum prolis) ${ }^{7}$. Bonum prolis przekazane $\mathrm{w}$ akcie zgody małżeńskiej ma charakter wyłączny i dozgonny, a więc niedopuszczający żadnych przerw i ograniczeń. Dlatego jego wykluczenie czasowe lub istotne ograniczenie narusza ważny element zgody małżeńskiej, powodując jej nieważność ${ }^{8}$.

Istotę symulacji częściowej w odniesieniu do bonum prolis dobrze ilustrują orzeczenia Roty Rzymskiej. Dość przywołać wyrok c. Burke z 15.10.1995, w którym czytamy: „Symulant, deklarując słowami lub znakami zewnętrznymi wolę zawarcia małżeństwa, poprzez wewnętrzną intencję odrzuca jakiś istotny element przymierza małżeńskiego. To wewnętrzne odrzucenie przymierza oznacza, że w rzeczywistości oponuje przeciwko całkowitemu oddaniu się małżeńskiemu. Wyraża on zgodę jedynie w częściowym przekazaniu swojej seksualności, gdyż wyklucza albo dozgonność tego oddania, albo jego wyłączność, albo jego prokreacyjność. Tego rodzaju ograniczone i uszczuplone przekazanie siebie jest nieskuteczne do zaistnienia małżeństwa. Kto oddaje się drugiej stronie zaledwie częściowo, nie oddaje się na sposób małżeński”"

6 Por W. Góralski, Wykluczenie prawa do potomstwa $w$ świetle nowszego orzecznictwa rotalnego, dz. cyt., s. 78 .

7 Por. M. Sable, Tradere et accipere: quaedam problemata de mutuo consensu circa ius ad prolem in causis matrimonialibus, „Periodica” 84 (1995), s. 767-770; L. Świto, Exclusio boni prolis jako tytuł nieważności małżeństwa, Olsztyn 2003, s. 61.

8 Por. dec. c. Huber z 26.11.1993, Rotae Romanae Tribunal. Decisiones seu Sententiae [dalej: RRDec.] 85 (1993), s. 724; dec. c. Funghini z 17.02.1988, RRDec. 80 (1988), s. 107; L. Świto, Exclusio boni prolis..., dz. cyt., s. 61.

9 Cyt. za: W. Góralski, Wykluczenie dobra potomstwa w nowszym orzecznictwie rotalnym, „Ius Matrimoniale” 9 (2004), s. 120-121. Tekst oryginalny: dec. c. Burke z 19.10.1995 r., 
Odrzucenie daru prokreacyjności oznacza, że ma miejsce wykluczenie dobra potomstwa in suis principiis ${ }^{10}$. Nadto należy przypomnieć opinie wybitnych kanonistów rotalnych, według których obowiązku współżycia małżeńskiego, ukierunkowanego do zrodzenia potomstwa, nie może spełnić osoba obciążana nieprzezwyciężalną awersją do poczęcia i zrodzenia dziecka ${ }^{11}$. Ów defekt może przejawiać się w praktyce na różne sposoby. Jak pokazują wyroki sądu biskupiego w Tarnowie, można go rozpoznać przez obsesyjne nastawienie osoby przeciwko poczęciu potomstwa, ujawniające się w stałym stosowaniu środków antykoncepcyjnych i wczesnoporonnych ${ }^{12}$.

Do istotnych obowiązków małżeńskich realizowanych w ramach bonum prolis zawsze należy, oprócz spełniania aktów małżeńskich, ochrona poczętego życia, dalej jego zrodzenie i utrzymywanie przy życiu oraz wychowanie $^{13}$. Osoby obciążone różnymi obsesjami i chorobami psychicznymi godzącymi w dobro rodziny, a więc także w przyszłe potomstwo, nie są zdolne do realizacji tak zaszczytnego i odpowiedzialnego zadania. Stwierdzając taki stan umysłu nupturienta, nie można ograniczyć się jedynie do przejrzenia kartoteki medycznej, lecz zawsze należy przeanalizować burzliwą przeszłość podmiotu, która w prosty sposób może wykazać nieszczerość składanych deklaracji.

RRDec. 87 (1995), s. 561: „Simulans dum verbis et signis externe quidem prolatis se foedus matrimoniale accipere declarat, per internam intentionem aliquod essentiale foederis elementum respuit. Haec interior foederis recusatio significat quod ille se alteri parti in totali coniugali donatione consentit, ex eo quod vel perpetuitatem donationis vel eius unicitatem vel eius procreativitatem excludit. Huiusmodi tam contracta ac mutilata suiipsius donatio inefficax est ad matrimonium constituendum. Qui se alteri partialiter tradit, se illi matrimonialiter non tradit".

${ }^{10}$ Por. W. Góralski, Wykluczenie dobra potomstwa w nowszym orzecznictwie rotalnym, dz. cyt., s. 120-121.

${ }^{11}$ Por. Problematyka dotycząca stosowania środków antykoncepcyjnych została ujęta i wyjaśniona w wyroku c. Burke z 1.03.199o, z którego jasno wynika, że poprzez stosowanie antykoncepcji małżonkowie zrzekają się wyjątkowego daru potomstwa, do którego winna prowadzić miłość małżeńska. Por. RRDec. 82 (1990), s. 407-430.

${ }_{12}$ Por. A. Gołębiewska, Forma wykluczenia bonum prolis $w$ doktrynie i orzecznictwie Roty Rzymskiej, „Ius Matrimoniale” 17 (2012), s. 67; S. Mojek, Antykoncepcja, [w:] Jan Pawet II. Encyklopedia nauczania moralnego, red. J. Nagórny, K. Jeżyna, Radom 2005, s. 62-65.

${ }^{13}$ Por. J. Krukowski, Wykluczenie potomstwa. Nowe tendencje $w$ orzecznictwie rotalnym, [w:] Kościót i Prawo, t. 3, Lublin 1984, s. 234-236. 


\section{I.I. Wykluczenie wyraźne}

Według kanonistyki wykluczenie dobra potomstwa może dokonać się w sposób wyraźny (wprost) i niewyraźny (nie wprost). Wykluczenie wyraźne ma miejsce wtedy, gdy pozytywny akt woli nupturienta skierowany jest przeciwko prawu do prokreacyjnego aktu małżeńskiego (ius ad coniugalem actum) lub prawu do potomstwa (ius ad prolem), bądź też prawu do integralnego wychowania dziecka (ius ad educationem) ${ }^{14}$.

Ponieważ w aktualnym Kodeksie zrodzenie potomstwa zakłada udzielenie sobie przez nupturientów prawa do aktów małżeńskich skierowanych ze swej natury do zrodzenia potomstwa (ius ad coniugalem actum), to jego odrzucenie stanowi przejaw wykluczenia bonum prolis - a więc istotnego elementu małżeństwa zawartego implicite w kan. $1055 \$ 1 \mathrm{KPK}$. Trzeba więc powiedzieć, że wykluczenie prawa do aktów małżeńskich, o których wprost wspominał dawny kodeks w kan. $1086 \$ 2$, stanowi w kontekście kan. 1055 $\$ 1$ i kan. $1101 \$ 2 \mathrm{KPK}$-wykluczenie istotnego elementu małżeństwa. W praktyce polega ono albo na całkowitym odrzuceniu, czyli nieprzekazaniu drugiej stronie należnego prawa, co może ujawniać się w uporczywej odmowie współżycia seksualnego, albo też na znacznym (istotnym) ograniczeniu tego prawa, polegającym bądź to na wykluczeniu jego ciągłości z jakiegoś okresu życia małżeńskiego, bądź też na rozdzieleniu nierozerwalnego $\mathrm{z}$ natury związku pomiędzy jednoczącym i prokreacyjnym znaczeniem małżeńskiego aktu seksualnego ${ }^{15}$. Ostatnia konfiguracja zachodzi, gdy jeden lub dwoje nupturientów podejmują w chwili wyrażania konsensusu małżeńskiego zamiar stosowania środków antykoncepcyjnych, redukując pożycie małżeńskie do wymiaru hedonistycznego, zamkniętego ze swej natury na dar nowego życia i poświęcenie się rodziców dla jego przyjęcia i wychowania ${ }^{16}$. Oddzielenie aktu od prokreacji zaprzecza pełnemu i wzajemnemu oddaniu się małżonków.

${ }^{14}$ Por. L. Świto, Exclusio boni prolis..., dz. cyt., s. 61.

15 Por. L. Świto, Exclusio boni prolis..., dz. cyt., s. 62; dec. c. Fiore z 25.02.1993 r., RRDec. 85 (1993), s. 57.

${ }^{16}$ Por. A. Stankiewicz, L'esclusione della procreatione ed educatione prole, [w:] La simulazione del consenso matrimoniale canonico, Città del Vaticano 1990, s. 161 (Studi Giuridici, 22); S. Olejnik, Teologia moralna życia społecznego, Włocławek 200o, s. 306-316; J. Bajda, Odpowiedzialne rodzicielstwo a antykoncepcja, „Communio” ed. pol. 4 (1984) nr 6, s. 102-121. 
Tymczasem copula perfecta humana dokonuje się wówczas, gdy małżonkowie w sposób najbardziej intymny, wolny i godziwy - a więc na sposób ludzki - łączą się ze sobą, nie wykluczając naturalnego ukierunkowania na dar potomstwa ${ }^{17}$. Oznacza to, że inny sposób wykonywania tego prawa nie może nosić nazwy pełnego aktu małżeńskiego ${ }^{18}$. Brak bowiem intencji przyjęcia potomstwa, które integralnie związane jest z wzajemnym obdarowaniem się, powoduje, że symulanci pozbawiają się gotowości do uczestniczenia $\mathrm{w}$ akcie stwórczym Boga ${ }^{19}$. Jak zaznaczono w orzeczeniu c. Burke z 1.03.1990, prokreacyjne ukierunkowanie aktu małżeńskiego zakłada już sama natura, gdyż tylko wtedy w najwyższym stopniu może ukazać się samoobdarowanie się małżonków: „Haec vero, quae dicitur, procreativitas, ius coniugale supponit. Re enim ius ad actus vere coniugales, ad vitam apertos, in ipsa natura coniugalis auto-donationis innitu, immo, ab ista natura exigitur"20. Z całą pewnością małżeństwo jest ku temu ukierunkowane ze swej natury i z tego tė̇ względu małżonkowie stają się jednym ciałem zgodnie ze wskazaniami kan. $1061 \$ 1 \mathrm{KPK}^{21}$. Stąd akt małżeński sztucznie pozbawiony swej naturalnej prokreacyjności (np. przez współżycie analne, stosowanie spirali wewnątrzmacicznej) nie będzie pełnym, ludzkim aktem małżeńskim, ale tak pojmowany i chciany, będzie stanowił podstawę do stwierdzenia nieważności małżeństwa z tytułu exclusio boni prolis ${ }^{22}$.

${ }_{17}$ Por. L. Świto, Exclusio boni prolis..., dz. cyt., s. 62.

${ }_{18}$ Por. M. F. Pompedda, La nozione di matrimonio "rato e consumato" secondo il can. $1061 \$ 1$, del CIC e alcune questioni processuali di prova in merito, „Monitor Ecclesiasticus” 110 (1985), s. 347-359.

19 Por. Jan Paweł II, adhort. apost. Familiaris consortio, 22.11.1981, [w:] Posoborowe dokumenty Kościoła katolickiego o małżeństwie i rodzinie, red. K. Lubowicki, t. 1, Kraków 1999, s. 165; Paweł vi, Humane vitae, 25.07.1968, [w:] Posoborowe dokumenty..., dz. cyt., S. 25.

${ }^{20}$ Por. dec. c. Burke z 1.03.1990 r., RRDec. 82 (1990), s. 183; W. Góralski, Wykluczenie dobra potomstwa w świetle wyroku Roty Rzymskiej. (Non constare) C. Burke z 1.03.199or., [w:] Przymierze małżeńskie, red. W. Góralski, R. Sztychmiler, Lublin 1993, s. 115-126; dec. c. Civili z 9.12.1992 r., RRDec. 84 (1992), s. 639-641; dec. Stankiewicz z 17.12.1993 r., RRDec. 85 (1993), s. 780.

${ }^{21}$ Por. A. Gołębiewska, Forma wykluczenia bonum prolis $w$ doktrynie i orzecznictwie Roty Rzymskiej, „Ius Matrimoniale” 17 (2012), s. 71.

${ }_{22}$ Por. H. Dobiosz, Nauczanie Kościoła o nierozerwalności podwójnego sensu aktu małżeńskiego, „Studia Teologiczno-Historyczne Śląska Opolskiego, 17 (1997), s. 103-110; L. Świto, Exclusio boni prolis..., dz. cyt., s. 63. 
Drugim rodzajem wykluczenia wyraźnego jest exclusio ad prolem. Dotyczy to sytuacji, w której nupturienci pozytywnym aktem woli nie wykluczają samego współżycia małżeńskiego, ale wykluczają potomstwo jako oczywisty i naturalny skutek podjętych aktów ludzkich. Chodzi o sytuacje, w których nupturienci w chwili wyrażania zgody małżeńskiej mieli bezwzględny zamiar przeciwdziałania poczęciu zawsze i za pośrednictwem różnorakich środków; intencję, która wykluczałaby zarówno poczęcie, jak i wydanie na świat dziecka oraz jego wychowanie ${ }^{23}$. Zachowanie to może polegać na niedopuszczeniu do ukończenia procesu prokreacyjnego poprzez zamiar stosowania antykoncepcji bądź dokonywania czynności prowadzących do przerwania już poczętego życia (abor$\left.c^{2 j a}\right)^{24}$ albo też - jak wykazuje nowsze orzecznictwo rotalne - na sprzyjaniu prokreacji sztucznej i autonomicznej, czyli niezależnej od aktu małżeńskiego ${ }^{25}$. W tym przypadku chodzi o różne praktyki, w których ma miejsce przeniesienie prokreacji poza naturalny akt małżeński, np. zapłodnienie in vitro ${ }^{26}$. Sędziowie Roty Rzymskiej w wielu orzeczeniach wyjaśniają, iż z przyjęciem i przekazaniem ius ad coniugalem actum związana jest prokreacja, która ukierunkowana jest ku bonum prolis. Chodzi zatem o wykluczenie skutków aktów właściwych zjednoczeniu małżeńskiemu, a więc wykluczenie prawa zrodzenia potomstwa $\mathrm{z}$ własnym małżonkiem. Wobec tego zamiar przeciwny potomstwu tylko wtedy unieważnia małżeństwo, gdy wyklucza potomstwo co do jego zasady w takiej sytuacji gdy ktoś całkowicie wyrzeka się zamiaru dziecka, czyli dobra potomstwa co do jego praw i obowiązków, a nie tylko dziecka ze swej istoty, a więc tego, co dotyczy efektywnej prokreacji, która dotyczy korzystania z prawa małżeńskiego.

W związku z tym pozytywna wola posiadania potomstwa nie może stanowić warunku sine qua non zawarcia małżeństwa. Dzieje się tak, gdyż w przypadku bezpłodności zgoda małżeńska może być ważna pomimo świadomości nupturientów (kontrahentów) o niemożności posiadania

${ }^{23}$ Por. A. Gołębiewska, Forma wykluczenia bonum prolis..., dz. cyt., s. 72.

${ }^{24}$ Por. R. Sztychmiler, Obowiązek ochrony życia poczętego, "Chrześcijanin w Świecie” 21 (1989), nr 6, s. 34-44; P. Kieniewicz, Aborcja, [w:] Jan Pawet II. Encyklopedia nauczania moralnego, dz. cyt., s. 37-42.

${ }^{25}$ Por. dec. c. Civili z 9.12.1992 r., RRDec. 84 (1992), s. 642-645; dec. c. Bruno Z 12.03.1993, RRDec. 85 (1993), S. 149.

${ }^{26}$ Por. L. Świto, Exclusio boni prolis..., dz. cyt., s. 63. 
potomstwa, ale zawsze z przyczyn niezależnych od ich woli (niepłodność $)^{27}$. Wobec tego duże znaczenie ma tu intencja przyjęcia potomstwa. Jeżeli ktoś pozytywnym aktem woli wyklucza prawo do potomstwa, które może być poczęte i zrodzone w powstającym małżeństwie, to zawiera je nieważnie ${ }^{28}$. Na każde poczęte dziecko rozciąga się więc obowiązek zachowania go przy życiu, ponieważ przyjęte prawo do aktów małżeńskich rodzi z konieczności obowiązek przyjęcia również istotnych obowiązków z nim związanych, a w tym przypadku ochrony życia poczętego. Inaczej mówiąc, wykluczenie obowiązku ochrony życia poczętego jako istotnego obowiązku i elementu małżeństwa powoduje nieważność umowy małżeńskiej ${ }^{29}$.

Trzecim rodzajem wykluczenia wyraźnego jest exclusio ius ad educationem. Zgodnie z tym, co zostało wcześniej powiedziane, bonum prolis zawiera w sobie obowiązek wychowania potomstwa. Taką konsekwencję łatwo zauważyć, analizując kan. $1055 \$ 1,1136$ KPK. Ten ostatni nakłada na rodziców ciężki obowiązek wychowania potomstwa pod względem fizycznym, społecznym, kulturalnym, moralnym i religijnym. Jest to odbicie wcześniejszego nauczania Kościoła zawartego chociażby w dokumentach Soboru Watykańskiego II: Gaudium et spes ${ }^{30}$, Dignitatis huma$n a e^{31}$ czy Gravissimum educationis ${ }^{32}$. Większość audytorów rotalnych skłania się ku opinii, zgodnie z którą na kanoniczną treść bonum prolis, będącego istotnym elementem przedmiotu zgody małżeńskiej, nie składa się wprost prawo do wychowania moralno-religijnego dziecka, lecz raczej prawo-obowiązek zapewnienia potomstwu minimum wychowania. Inaczej mówiąc, prawo do wychowania katolickiego, choć niewątpliwie ważne i obwarowane nakazami moralnymi, których niespełnienie pociąga za sobą sankcje karne nałożone na rodziców dziecka ${ }^{33}$, nie należy

${ }_{27}$ Por. A. Gołębiewska, Forma wykluczenia bonum prolis..., dz. cyt., s. 72; L. Świto, Exclusio boni prolis..., dz. cyt., s. 65.

${ }^{28}$ Por. C. Burke, „Bonum coniugum” e il „bonum prolis”: fini o proprietà del matrimonio?, "Apollinaris" 62 (1989), s. 569; dec. c. Stankiewicz z 17.12.1993, RRDec. 85 (1993), s. 780.

${ }^{29}$ Por. J. Krukowski, Wykluczenie potomstwa. Nowe tendencje..., dz. cyt., s. 236.

${ }^{30}$ Por. Sobór Watykański II, konst. Gaudium et spes [dalej: KDK], 52.

${ }^{31}$ Por. Sobór Watykański II, dekl. Dignitatis humanae, 5.

${ }^{32}$ Por. Sobór Watykański II, dekl. Gravissimum educationis, 3.

${ }^{33}$ Por. kan. 1366 KРК: „,Rodzice lub ich zastępcy, którzy oddają dzieci do chrztu lub na wychowanie w religii niekatolickiej, powinni być ukarani cenzurą lub inną sprawiedliwą karą”. 
do istoty zgody małżeńskiej, a zatem jego wykluczenie w chwili wyrażania zgody małżeńskiej przez nupturienta nie powoduje wprost wady zgody małżeńskiej, chyba że wykluczenie tego elementu stanowiłoby część składową ekskluzji obowiązku wychowania in se. A zatem tylko takie wykluczenie wychowania potomstwa będzie powodowało nieważność umowy małżeńskiej, które będzie się wiązało z zamiarem uniemożliwienia narodzonemu dziecku prawa do elementarnego wzrostu i rozwoju osoby ludzkiej we wspólnocie małżeńskiej ${ }^{34}$.

\section{I.2. Wykluczenie niewyraźne}

Poza wykluczeniem wyraźnym kanonistyka wyróżnia jeszcze tzw. wykluczenie niewyraźne. Ma ono miejsce wtedy, gdy nupturienci, przystępując do zawarcia małżeństwa, nie wykluczają wprost aktów małżeńskich, samego potomstwa i jego wychowania. W praktyce wygląda to tak, iż osoby te przystępują do wyrażenia zgody małżeńskiej z powziętym postanowieniem nieprzyjmowania od razu zadania i trudu rodzenia dzieci. Odkładają ich poczęcie i zrodzenie na czas późniejszy (bliżej nieokreślony), bardziej dla nich dogodny albo też zawierają małżeństwo $\mathrm{z}$ decyzją wyznaczającą czas poczęcia i liczbę potomstwa, i dlatego za wzajemną zgodą powstrzymują się w określonych terminach od współżycia seksualnego ${ }^{35}$. Sędziowie rotalni, wypowiadając się na ten temat, wskazują na kilka przyczyn takiego stanu rze$\mathrm{czy}^{36}$. Wśród najliczniejszych wymienia się brak gotowości młodego pokolenia do ofiary i poświęcenia, chęć przedłużenia narzeczeństwa w małżeństwie, ustalanie tak zwanego „małżeńskiego okresu próbnego”, a także motywy ekonomiczne, na które składają się brak pracy oraz dążenie do zapewnienia sobie i potomstwu lepszych warunków material-

${ }^{34}$ Por. L. Świto, Exclusio boni prolis..., dz. cyt., s. 66; trzeba także dodać, iż wolność w wychowaniu zapewnia także polski porządek prawny. Dość wspomnieć art. 48 ust. 1 Konstytucji RP; art. 12 ust. 1 Konkordatu między Stolicą Apostolską a RP, a także art. 18 ust. 1 Ustawy z dnia 17 maja 1989 r. o stosunku Państwa do Kościoła katolickiego w Polskiej Rzeczypospolitej Ludowej.

${ }_{35}$ Por. L. Świto, Exclusio boni prolis..., dz. cyt., s. 67.

${ }^{36}$ Por. A. Stankiewicz, De iurisprudentia recentiore circa simulationem totalem et partialem, wyd. 2, Romae 1989, s. 74. 
nych $^{37}$. Nadto decydującym motywem jest również okres choroby i rekonwalescencji ${ }^{3}$. Z doktryny i orzecznictwa Roty Rzymskiej wynika, że odłożenie na pewien czas poczęcia potomstwa nie niweczy celu, do którego małżeństwo jest skierowane ze względu na swoją istotę ${ }^{39}$. Trzeba jednak zwrócić uwagę na fakt, że nie może to oznaczać, iż temu prawu odbiera się pozytywnym aktem woli możności ciągłego obowiązywania. Wynika z tego, że małżonkowie, którzy z pewnych względów odkładają na pewien czas zrodzenie potomstwa, nie mogą wyrzec się gotowości jego przyjęcia, gdyby jednak zostało poczęte ${ }^{40}$. Wykluczenie niewyraźne, obejmujące czasowe odłożenie potomstwa lub ograniczenie jego liczebności, nie musi oznaczać nieważności małżeństwa. Takie postanowienie, jeśli nie przekreśla celu, do którego małżeństwo kieruje się ze swej istoty, nie powoduje wady konsensusu małżeńskiego ${ }^{41}$ ani też nie usuwa intencji zrodzenia potomstwa, bez której ono nie może zaistnieć ${ }^{42}$.

${ }^{37}$ Por. dec. c. Huber z 24.11.1995, RRDec. 87 (1995), s. 636; dec. c. Bruno z 12.03.1993, RRDec. 85 (1993), s. 145-146; dec. c. De Lanversin z 10.11.1992, RRDec. 84 (1992), s. 537.

${ }_{38}$ Por. M. Żurowski, Kanoniczne prawo małżeńskie Kościoła katolickiego, Katowice 1987, s. 260; R. Sztychmiler, Implikacje procesowe ujęcia celów małżeństwa w Kodeksie Prawa Kanonicznego z 1983 r., [w:] Przymierze matżeńskie, dz. cyt., s. 90.

${ }^{39}$ Por. R. Sztychmiler, Istotne obowiązki matżeńskie, Warszawa 1997, s. 228; K. Majdański, Populacja - problem rodziny ludzkiej, „Ateneum Kapłańskie” 84 (1975), s. 201-238. Więcej na ten temat: J. i S. Kippley, Sztuka naturalnego planowania rodziny, tłum. M. i R. Toporkiewiczowie, Warszawa 1987.

${ }^{40}$ Por. Jan Paweł II, Modlitwa niedzielna z Papieżem 17.07.1994 w Castel Gandolfo: „W podejmowaniu decyzji o tym, czy przekazać życie lub tego nie czynić, małżonkowie nie powinni ulegać egoizmowi ani dać się ponieść lekkomyślności, lecz kierować się roztropną i świadomą wielkodusznością, która potrafi ocenić możliwości i warunki i zadbać przede wszystkim o dobro mającego się narodzić dziecka”, „L'Osservatore Romano” (wyd. pol.) 9-10 (1994), s. 32; por. A. Gołębiewska, Forma wykluczenia bonum prolis..., dz. cyt., s. 74.

${ }^{41}$ Dec. c. Palestro Z 19.05.1993 r., RRDec. 85 (1993), s. 398: „Qui finem habet differendi prolis procreationem ad tempus aptum non destruit finem ad quem natura sua matrimonium ordinatur, unde valide contrahit".

${ }^{42}$ Dec. c. De Jorio z 22.07.1964 r., SRRDec. 56 (1964), s. 644: „At propositum vitandi prolem, etsi in ipso consensu praestando initum atque expressum, non irritat matrimonium si ad tempus sit, cum in hypothesi non desit intentio filium seu filios generandi”. Należy przy tym zaznaczyć, że zwrot „czasowe wykluczenie potomstwa” nie utożsamia się z „czasowym wykluczeniem bonum prolis". Wykluczenie bowiem: czy to czasowe, czy na stałe bonum prolis, zawsze - w odróżnieniu od czasowego wykluczenia potomstwa - będzie powodowało nieważność małżeństwa. Por. L. Świto, Exclusio boni prolis..., dz. cyt., s. 68. 
Analizując to zagadnienie, należy odróżnić pojęcie samego prawa od jego wykonywania. O ważności umowy małżeńskiej decyduje niewykluczenie przez nupturientów tego prawa w chwili wyrażania zgody, a nie późniejsze wykonywanie tego prawa. Stąd w orzecznictwie i kanonistyce wykorzystuje się zasadę rozróżniającą ipsum ius od usus iuris. Zachodzi więc istotna różnica między wykluczeniem samego prawa (ipsum ius) a postanowieniem jedynie niewykonywania tego prawa (exercitium iuris) bądź nie korzystania z niego (usus iuris). Tylko exclusio ipsum ius, a nie usus iuris, powoduje wadliwość zgody małżeńskiej - a więc nieważność samego małżeństwa ${ }^{43}$. Kanonistyka, stosując to rozróżnienie, opiera się na doktrynie św. Tomasza z Akwinu oraz jego ucznia Tomasza Sancheza. W swojej argumentacji nawiązywali oni do prawa rzymskiego, według którego właściciel posiadający własność zachowywał prawo do rzeczy mimo, że zrzekał się prawa do jej użytkowania. Sanchez pisał, że „istota trzech dóbr małżeńskich polega nie na ich wykonywaniu, lecz na obowiązku polegającym na tym, że małżonkowie zobowiązują się do nierozdzielnego i dozgonnego pożycia i do wzajemnego dochowania wierności, oddając powinność co do ciała (co do aktów małżeńskich) i nie przeszkadzając zrodzeniu potomstwa, lecz wychowując, gdyby Bóg je dał" ${ }^{44}$.

Natomiast co do stanowiska przeciwników wyżej wskazanego rozróżnienia, to ich argumentacja zmierza do wykazania, iż intencja przyjęcia danego obowiązku i jednocześnie intencja niewypełnienia go nie mogą ze sobą współistnieć, ale pozostają ze sobą w sprzeczności. Dobrym przykładem takiego stanowiska jest orzeczenie c. Bruno z 19.12.1995 ${ }^{45}$. Trzeba jednak przyłączyć się do zdecydowanej większości reprezentowanych przez c. Hubera. Według niego „sprzecznością jest jednoczesna intencja podjęcia obowiązku i intencja nieprzyjęcia obowiązku do wypełnienia, jednak sprzecznością nie jest jednoczesna wola przyjęcia obowiązku

${ }^{43}$ Por. P. Bianchi, Lesclusione della prole nella giurisprudenza della Rota Romana dal CIC 1983, [w:] Prole e matrimonio canonico, Città del Vaticano 2003, s. 119-125 (Studi Giurdici, 62).

${ }^{44}$ L. Świto, Exclusio boni prolis..., dz. cyt., s. 73-74.

45 „Consensus matrimonialis proprie dictus, cum voluntate non adimplendi obligationem, nihil aliud esse nisi voluntas sumendi obligationem una cum voluntate excludendi obligationem adimplendi, id est voluntas sumendi obligationem et simul voluntas obligationem non sumendi: quod est contradictorium". Cyt. za: W. Góralski, Wykluczenie dobra potomstwa w nowszym orzecznictwie rotalnym, dz. cyt., s. 126. 
i wola niewypełnienia przyjętego obowiązku, ponieważ przedmiot woli jest tutaj różny i odrębny. Żadna niemożliwość logiczna, żadna sprzeczność per se nie zachodzi pomiędzy jedną i drugą wolą. Rozróżnienie zatem pomiędzy ius i usus iuris należy zachować" ${ }^{46}$. Takie rozróżnienie sprawia, że w poszczególnych wypadkach niezbędne jest jednoznaczne ustalenie, czy ekskluzja dotyczyła samego prawa, czy korzystania $\mathrm{z}$ niego. Trzeba zatem wziąć pod uwagę przedmiot i formę wykluczenia. Najważniejszą kwestią jest ustalenie, czy w momencie zawierania małżeństwa wola nupturientów była wolą prawdziwie małżeńską (w znaczeniu wyżej przedstawionym) ${ }^{47}$.

Zgodnie z prezentowaną zasadą judykatura Roty Rzymskiej stosuje pewne presumpcje, w myśl których czasowe wykluczenie zrodzenia potomstwa, polegające na decyzji nupturientów o odłożeniu jego zrodzenia na pewien czas lub decyzji dotyczącej określenia liczby zrodzonego potomstwa, nie będzie powodować nieważności małżeństwa, pod warunkiem że ipsum ius ad coniugalem actum w dalszym ciągu jest odpowiednio przekazywane i przyjmowane. Jest tak, poniewaz $\dot{z}^{48}$ :

1. Czasowe wykluczenie potomstwa rodzi domniemanie odmowy korzystania $\mathrm{z}$ ius ad prolem. Zamiar zaś nadużycia prawa nie narusza w najmniejszym stopniu samego prawa (ius ad prolem) ${ }^{49}$.

2. Czasowe wykluczenie zrodzenia potomstwa rodzi domniemanie odmowy używania lub wykonywania prawa do aktów małżeńskich, natomiast wykonywanie prawa nie należy do istoty kontraktu, dlatego jego odmowa (uszczuplenie) albo odwołanie dołącza się do samego kontraktu tylko „na sposób”, „na kształt”.

3. Czasowe wykluczenie zrodzenia potomstwa rodzi domniemanie wstrzymania się, zawieszenia wykonywania tego prawa (suspendenti ad tempus eius exsecutionem $)^{51}$.

${ }^{46}$ W. Góralski, Wykluczenie dobra potomstwa $w$ nowszym orzecznictwie rotalnym, dz. cyt., s. 126-127 (tekst oryginalny: dec. c. Huber z 6.05.1997, RRDec. 89 (1997), s. 375).

${ }_{47}$ Por. W. Góralski, Wykluczenie dobra potomstwa w nowszym orzecznictwie rotalnym, dz. cyt., s. 127 .

${ }^{48}$ Por. L. Świto, Exclusio boni prolis..., dz. cyt., s. 74.

49 Por. dec. c. Filipiak z 5.11.1965, SRRDec. 57 (1965), s. 784.

${ }^{50}$ Por. dec. c. Davino z 25.01.199o, RRDec. 82 (1990), s. 21.

${ }^{51}$ Por. dec. c. Pinto z 20.07.1972, SRRDec. 64 (1972), s. 482. 
W takich sytuacjach istnieje intencja posiadania potomstwa, chociaż jej wypełnienie i aktualizacja odłożone są na późniejszy czas. Naturalnie, o ile można zastanawiać się nad negatywnym wpływem takiej decyzji na umocnienie więzi małżeńskiej, o tyle uciekanie się do takich środków w niektórych przypadkach może odpowiadać tzw. idei prokreacji odpowiedzialnej. Na jej temat wypowiadało się wiele razy Magisterium Kościoła. Dość wspomnieć Piusa XII i jego przemówienia do położnych ${ }^{52}$ oraz do rodzin ${ }^{53}$. Także Jan Paweł II nauczał, że odpowiedzialna prokreacja istnieje nie tylko wtedy, gdy małżonkowie są otwarci na życie, ale również wtedy, gdy na skutek poważnych i obiektywnych przyczyn oraz nakazów moralnych postanawiają na określony czas nie wydawać na świat kolejnego potomstwa ${ }^{54}$. Największą zasługę w tym względzie ma Sobór Watykański iI, który od małżonków będących współpracownikami miłości Boga żąda odpowiedzialności ludzkiej i chrześcijańskiej55. Ewentualną decyzję o czasowym odłożeniu potomstwa małżonkowie winni podejmować wspólnie ${ }^{56}$, zawsze $\mathrm{z}$ ważnych motywów, uwzględniających uwarunkowania czasu, warunki materialne i kondycję psychiczną ${ }^{57}$. Nadto nie mogą kierować się konformizmem, lecz podejmując decyzję, winni uwzględniać dobro społeczeństwa i Kościoła ${ }^{58}$. Dopiero tak ustawiona regulacja poczęć, wolna od metod i środków potępionych przez nauczanie Kościoła, staje się godziwa i dopuszczalna ${ }^{59}$.

Tę soborową zasadę odpowiedzialnego rodzicielstwa (paternitatas responsabilis) podjął Paweł vi w encyklice Humanae vitae. Pisał w niej, że małżonkowie poprzez znajomość i odpowiedni wybór dni płodnych i niepłodnych mają prawo do roztropnego i pełnego miłości planowania swojej rodziny. Jednocześnie papież wykluczył stosowanie antykoncepcji,

52 Por. Pius XII, Allocutiones, 29 X 1951, AAS 43 (1951), s. 846.

53 Por. Pius XII, Allocutiones, 26 XI 1951, AAS 43 (1951), s. 859.

${ }_{54}$ Por. W. Góralski, Wykluczenie dobra potomstwa w nowszym orzecznictwie rotalnym, dz. cyt., s. 128; W. Gubała, Podstawa odpowiedzialnego rodzicielstwa i jej teologiczny fundament, „Homo Dei” 63 (1989) nr 4, s. 277-286.

${ }_{55}$ Por. KDK 50.

${ }^{56}$ KDK 51.

${ }^{57}$ Por. KDK 50; P. Bianchi, Lesclusione della prole nella giurisprudenza della Rota Romana dal CIC 1983, [w:] Prole e matrimonio canonico, Città del Vaticano 2003, s. 125-126 (Studi Giuridici, 62).

${ }^{58}$ Por. Katechizm Kościoła Katolickiego [dalej: KKK], 2368.

59 Por. KDK 51. 
sterylizacji czy spędzanie płodu, a liczną rodzinę ukazał jako wzór ofiary i miłości chrześcijańskiej ${ }^{60}$. W podobny sposób zasady te zostały powtórzone przez Stolicę Apostolską w Karcie Praw Rodziny z 22.10.1983 ${ }^{61}$. Nadto trzeba pamiętać, iż zasada odpowiedzialnej prokreacji kierowana jest bardziej do małżonków niż nupturientów, to znaczy dotyczy bardziej małżeństwa in facto esse, nie zaś intencji nupturientów w momencie wyrażania przez nich zgody. Małżonkowie, którzy w momencie zawierania małżeństwa nie powzięli żadnej decyzji co do ilości dzieci i czasu ich urodzenia, mogą z chrześcijańską odpowiedzialnością zadecydować o tym w czasie trwania małżeństwa. Jest to dość istotne, gdyż ich decyzja podjęta już w małżeństwie nie ma żadnego jurydycznego znaczenia dla wartości konsensusu małżeńskiego. Sobór w żaden sposób nie zamierza usprawiedliwiać całkowitej rezygnacji z potomstwa, gdyż to byłoby przeciwne naturze małżeństwa. Ważność zgody małżeńskiej pozostaje nienaruszona tylko wtedy, gdy kontrahenci nie wykluczają prokreacji w sposób całkowity i na zawsze. Żaden z nupturientów decydujących się na świadomą prokreację nie może wykluczyć rozsądnego żądania drugiej strony, gdyby ta nagle zmieniła zdanie i domagała się prawa-obowiązku spełnienia pełnego aktu małżeńskiego otwartego na zrodzenie potomstwa, ani nie może przeszkadzać już poczętemu potomstwu, gdyby akt ten okazał się płodny ${ }^{62}$. Dlatego „zasadę odpowiedzialnej prokreacji można przywołać tylko w sprawie, gdy chodzi o decydowanie, czy powiększyć, czy też nie ilość dzieci, a nie w sprawie decydowania w ogóle: powoływać do życia (kreować) czy nie powoływać (nie kreować) potomstwa" ${ }^{63}$. Natomiast nieważność małżeństwa będzie zachodziła wówczas, gdy wiadomy był zamiar czasowego wykluczenia bonum prolis, podjęty w sposób absolutny lub warunkowy lub gdy znany był zamiar wykluczenia zrodzenia potomstwa na zawsze. Samo postanowienie czasowego unikania potomstwa nie będzie rodziło domniemania o wykluczeniu

${ }^{60}$ Por. Paweł VI, Humanae vitae, 10; W. Szewczyk, O małżeństwie i rodzinie, „Homo Dei” 63 (1994) nr 1, s. 117-130; B. Inlender, Normy etyczne w encyklice Humanae vitae i ich uzasadnienie, „Collectanea Theologica” 39 (1969) nr 4, s. 33-48; J. Bajda, Odpowiedzialne rodzicielstwo a antykoncepcja, „Communio” 4 (1984) nr 6, s. 102-115.

${ }^{61}$ Por. L. Świto, Exclusio boni prolis..., dz. cyt., s. 74.

${ }^{62}$ Por. dec. c. Stankiewicz z 29.07.1979 r., RRDec. 72 (1980), s. 559-563.

${ }^{63}$ L. Świto, Exclusio boni prolis..., dz. cyt., s. 72-73. 
bonum prolis ${ }^{64}$. Czym innym jest zawiesić na pewien czas zaakceptowane i niewykluczone prawo, a czym innym to uprawnienie wykluczyć bezwzględnie lub ze względu na jakiś warunek. Jest rzeczą istotną, aby małżonkowie byli zobowiązani do nierozdzielnego pożycia, spełniając względem siebie prawa i obowiązki i nie przeszkadzając zrodzeniu potomstwa, lecz wychowując je, gdy się narodzi ${ }^{65}$.

\section{Dowodzenie sądowe}

Dowodzenie sądowe w sprawach symulacji nie należy do łatwych. Trzeba bowiem wykazać, iż kontrahent pozytywnym aktem woli wykluczył samo małżeństwo albo jakiś istotny element małżeństwa lub też jego istotny przymiot $^{66}$. Po stwierdzeniu faktu symulacji, który w naszym przypadku odnosi się do wykluczenia dobra potomstwa, następuje obalenie domniemania prawnego wynikającego z kan. $1101 \$ 1 \mathrm{KPK}$, zgodnie z którym wewnętrzna zgoda odpowiada wypowiadanym słowom lub używanym znakom. Należy zatem w procesie udowodnić, i to ponad wszelką wątpliwość, że w momencie zawierania małżeństwa miał miejsce pozytywny akt woli zakładający coś przeciwnego w stosunku do wypowiadanych słów (lub czynionych gestów), a więc akt woli wykluczający istotny element małżeństwa, jakim jest bonum prolis ${ }^{67}$. Bez udowodnienia takiego pozytywnego aktu woli albo, inaczej mówiąc, bez obalenia wyżej przytoczonego domniemania prawnego nie można stwierdzić nieważności małżeństwa ${ }^{68}$. Trudność procesowa polega na tym, iż sędzia musi do-

${ }^{64}$ Por. K. Konieczny, Nieważność małżeństwa z tytułu wykluczenia potomstwa, „Ateneum Kapłańskie" 56 (1958), s. 429.

${ }^{65}$ Por. L. Świto, Exclusio boni prolis..., dz. cyt., s. 85; dec. c. Fiore z 25.02.1993, RRDec. 85 (1993), s. 57-58; dec. c. Huber z 26.11.1993, RRDec. 85 (1993), s. 725; dec. c. Brennan Z 24.10.1966, SRRDeC. 58 (1966), s. 724.

${ }^{66}$ Por. kan. $1101 \$ 2 \mathrm{KPK}$; T. Pawluk, Kanoniczne procesy szczególne. Zarys prawa kanonicznego, t. 4, z. 3, Warszawa 1971, s. 250-255.

${ }^{67}$ Por. R. Sztychmiler, Wykluczenie potomstwa $w$ świetle najnowszego orzecznictwa Roty Rzymskiej, „Ius Matrimoniale” 5 (2000), s. 113; L. Świto, Exclusio boni prolis..., dz. cyt., s. 86; A. Gołębiewska, Forma wykluczenia bonum prolis..., dz. cyt., s. 72.

${ }^{68}$ Dec. c. Pinna z 28.11.1959, SRRDec. 51 (1959), s. 572: „Arduum sane est practice discernere utrum agatur de ipso iure an de ipso iure an de exercitio dumtaxat exclusio: sedulo rimanda sunt acta atque verba simulantis, tempore non suspecto prolata, perpendenta, non in cortice, sed interius perspecta firmitate propositi, perpetuitate exclusionis, insuperabili 
trzeć (dokonać analizy) do prawdziwej woli kontrahenta, jaką przejawiał w chwili wyrażania zgody małżeńskiej, i ocenić, czy jego wola prawdziwie, czy tylko pozornie była otwarta na przyjęcie potomstwa ${ }^{69}$. Naturalnie, zgodnie z kan. $1526 \$ 1 \mathrm{KPK}$, ciężar dowodzenia spoczywa na tym, kto twierdzi, że symulacja miała miejsce (onus probandi incumbit ei qui asserit $)^{70}$. Ponadto sędzia, wydając wyrok o nieważności małżeństwa, musi mieć tzw. pewność moralną, zdobytą na podstawie udowodnionych faktów zaczerpniętych od stron i wiarygodnych świadków, jak również na podstawie poszlak, okoliczności i domniemań ${ }^{71}$.

W jurysprudencji Roty Rzymskiej dawno przyjęto podział dowodzenia wykluczenia dobra potomstwa na dowodzenie bezpośrednie (probatio directa) i dowodzenie pośrednie (probatio indirecta).

\section{I. Dowodzenie bezpośrednie}

Dowód bezpośredni stanowi zeznanie samego kontrahenta, który dopuścił się symulacji zgody małżeńskiej (confessio simulantis), poparte zeznaniami współmałżonka i innych światków, jak również istniejącymi dokumentami. Chodzi zatem o wszelkie środki, które świadczą wprost o woli wykluczenia boni prolis przez kontrahenta lub obydwu kontrahentów. Zeznanie bezpośrednie może być sądowe (confessio iudicialis) oraz pozasądowe (confessio extraiudicialis). Zdaniem wybitnych kanonistów wartościowsze dla sprawy jest wyznanie pozasądowe. Polega ono na wypowiadaniu się przez symulującego do osób trzecich (tempore non suspecto) o powziętej przed ślubem intencji wykluczenia dobra potomstwa. Inaczej mówiąc, jest to spontaniczne informowanie drugiej strony, krewnych, bliskich czy znajomych o powziętym zamiarze. Taka spontaniczność, ujawniona w „czasie niepodejrzanym”, może pomóc sędziemu w rozstrzygnięciu sprawy ${ }^{72}$. Ważne jest, aby dokonując oceny

tenacitate in eodem exsequendo, causa in aestimatione eiusdem adequanta et praevalenti, seu quae iudicio ipsius gravior sit causa contrahendi".

${ }^{69}$ Por. W. Góralski, Wykluczenie dobra potomstwa w nowszym orzecznictwie rotalnym..., dz. cyt., s. 121-125; M. Sitarz, Słownik prawa kanonicznego. Proces, Warszawa 2004, kol. 141.

70 Por. KPK 1917 kan. 1748 \$1; T. Pawluk, Kanoniczne procesy szczególne. Zarys prawa kanonicznego, t. 4, z. 3, Olsztyn 1983, s. 256.

${ }^{71}$ Por. L. Świto, Exclusio boni prolis..., dz. cyt., s. 86-87.

72 Por. L. Świto, Exclusio boni prolis..., dz. cyt., s. 109. 
wypowiedzianych słów, nie skupiać się wprost na ich dosłowności, lecz raczej wiązać je z okolicznościami, w których zostały wypowiedziane, oraz uwzględnić wykształcenie osoby, kulturę i mentalność. Gdyby jednak symulujący nie informował nikogo o powziętej intencji wykluczenia dobra potomstwa, nie czyni to niemożliwym wydanie wyroku stwierdzającego nieważność, lecz z pewnością samo dowodzenie czyni o wiele trudniejszym. Podobna trudność zachodzi, gdy pozwany zaprzecza symulacji, składa sprzeczne zeznania albo też wykazuje symptomy zaburzeń psychicznych ${ }^{73}$. W takiej sytuacji, jak stwierdza kan. $1679 \mathrm{KPK}$, istotną rolę odgrywają wiarygodni świadkowie ${ }^{74}$.

Zeznanie sądowe (confessio iudicialis) to zwykłe zeznanie strony symulującej, złożone ustnie bądź pisemnie sędziemu, w toku trwania przewodu sądowego. Jego znaczenie jest duże, gdyż jedynie on zna dokładnie swoją wolę ukształtowaną w chwili zawierania małżeństwa. Ponieważ to zeznanie $\mathrm{z}$ oczywistych względów może być tendencyjne, a nawet fałszywe, należy zachować roztropną ostrożność i zapoznać się ze świadectwem kwalifikacyjnym takiej osoby ${ }^{75}$. Pisze o tym c. Stankiewicz w orzeczeniu z 17.12.1993: „Sed confessio simulantis extra iudicium et in iudicio facta, etiamsi sit in favorem simulationis, vin plenae probationis non obtinet, nisi alia accedant elementa, quae eam omnino corroborent" ${ }^{\prime 6}$.

Innym elementem tego rodzaju zeznania jest confessio drugiej strony, która wypowiada się o czasie i okolicznościach, w których dowiedziała się o intencji przeciwnej dobru potomstwa. Takie zeznanie, ze względu na groźbę kłamstwa i złośliwości, musi być również skonfrontowane $\mathrm{z}$ innymi zeznaniami, dowodami i okolicznościami ${ }^{77}$. W zadawaniu

${ }^{73}$ Por. L. Świto, Exclusio boni prolis..., dz. cyt., s. 108.

${ }^{74}$ KPK kan. 1679: „Jeśli nie ma skądinąd pełnych dowodów, sędzia dla oceny zeznań stron według przepisu kan. 1536 powinien się posłużyć, jeżeli to możliwe, świadkami co do prawdomówności samych stron, oprócz innych poszlak i wskazówek".

${ }^{75}$ Por. E. Sztafrowski, Motywy orzeczenia ważności małżeństwa zaskarżonego z tytułu całkowitej symulacji w praktyce Roty Rzymskiej, [w:] Kościół i Prawo, t. 3, Lublin 1984, s. 159-160; J. Grzywacz, Wykluczenie „boni fidei”, [w:] Kościót i Prawo, t. 3, dz. cyt., s. 221;

L. Świto, Exclusio boni prolis..., dz. cyt., s. 88.

${ }^{76}$ Dec. c. Stankiewicz Z 17.12.1993, RRDec. 85 (1993), s. 783.

77 Por. W. Góralski, Exclusio boni prolis jako przyczyna nieważności małżeństwa w świetle nowszej jurysprudencji rotalnej, „Prawo Kanoniczne” 18 (1975) nr 3-4, s. 111; T. Pawluk, Kanoniczne procesy szczególne..., dz. cyt., s. 265-269. 
pytań należy rozróżnić absolutne wykluczenie boni prolis od czasowego odłożenia potomstwa. Ponieważ zeznania kontrahentów o dokonanej symulacji nie wyczerpują całości dowodu bezpośredniego, wymaga się zeznań świadków, którzy tempore non suspecto dowiedzieli się od symulanta o wykluczeniu przez niego dobra potomstwa. Na szczególną uwagę zasługują tu zeznania rodziców i krewnych kontrahentów, którzy mogą znać wiele faktów $\mathrm{z}$ okresu przedślubnego i sposobu pojmowania małżeństwa przez narzeczonych ${ }^{78}$.

Nadto do dowodów bezpośrednich zalicza się jeszcze dokumenty, a wśród nich szczególne znaczenie mają ewentualne formalne akty, spisane i podpisane przez strony, świadczące o wykluczeniu, przynajmniej przez jedną ze stron małżeństwa, otwartych na prokreację aktów seksualnych bądź też prawa dobra potomstwa jako takiego ${ }^{79}$.

\subsection{Dowodzenie pośrednie}

Przedstawiony wyżej dowód bezpośredni powinien być wzmocniony i poparty dowodem pośrednim, na który składają się przyczyna symulacji (causa simulationis) oraz okoliczności związane z zawarciem danego małżeństwa (circumstantiae).

Aby symulacja zgody małżeńskiej w odniesieniu do dobra potomstwa mogła być przyjęta i udowodniona, winna opierać się na ściśle sprecyzowanym motywie, nazywanym też źródłem, racją, czyli przyczyną symulacji. Człowiek bowiem zawsze kieruje się odpowiednią i motywującą przyczyną. Podjęty pozytywny akt woli przeciwny boni prolis kształtuje się w całej osobowości człowieka, w jego myśleniu i mentalności ${ }^{80}$. Trzeba zaznaczyć, iż przyczyna symulacji nie jest tożsama z przyczyną małżeństwa (causa contrahendi). W przypadku rzeczywistej symulacji causa simulationis musi niejako przezwyciężyć przyczynę zawarcia małżeństwa. „Mają wówczas miejsce dwa akty woli: $\mathrm{z}$ jednej strony kontrahent chce zawrzeć małżeństwo, lecz - z drugiej strony - wyklucza

${ }^{78}$ Por. G. Erlebach, Niektóre procesy specjalne, [w:] Komentarz do Kodeksu Prawa kanonicznego. T. 5. Ks. 7, Procesy, red. J. Krukowski, Poznań 2007, s. 325.

79 Por. W. Góralski, Exclusio boni prolis jako przyczyna nieważności małżeństwa w świetle nowszej jurysprudencji rotalnej, dz. cyt., s. 113.

${ }^{80}$ Por. L. Świto, Exclusio boni prolis..., dz. cyt., s. 94. 
prawo do ciała. Ten drugi akt woli pozbawia niejako mocy prawnej akt pierwszy, mocą którego kontrahent pragnie małżeństwa" ${ }^{\text {.1 }}$. Porównując te dwie przyczyny, sędzia musi upewnić się, że przeważyła ta ostatnia. Poza tym przyczyna symulacji winna być decydująca (causa motiva), a nie tylko skłaniająca (causa impulsiva). Przyczyna decydująca to taka, która skutecznie wpływa na exclusio boni prolis, a nie tylko przemawia za takim wykluczeniem. Następnie winna odznaczać się rozumnością (causa rationabilis), ciężkością (causa gravis), realnością (causa realis), nagłością (causa urgens), absolutnością (causa absoluta) oraz trwałością (causa tenax) ${ }^{82}$. Wymienione przymioty przyczyny wykluczenia dobra potomstwa należy oceniać subiektywnie, a zatem według oceny samego symulanta, pochodzącej z czasu powzięcia intencji przeciwnej boni prolis. Dlatego, biorąc pod uwagę wszelkie okoliczności, trzeba się upewnić, czy dana causa simulationis w konkretnym przypadku sądowym w ocenie symulującego uchodziła za poważną i z jakiego powodu ${ }^{83}$.

Orzecznictwo Roty Rzymskiej ustaliło szereg domniemań sędziowskich przyjmujących pewne fakty jako przyczyny symulacji wystarczające, a inne jako niewystarczające. Analizując wyroki rotalne, można stwierdzić, że najczęstszymi przyczynami wykluczenia dobra potomstwa są: awersja do dzieci ${ }^{84}$, blokada psychiczna w spełnianiu aktów seksualnych, poważna choroba jednej ze stron i obawa obciążenia genetycznego dziecka ${ }^{85}$, egoizm i wygodnictwo ${ }^{86}$, lęk przed porodem ${ }^{87}$, ateizm i nienawiść do religii ${ }^{88}$,

${ }^{81}$ W. Góralski, Exclusio boni prolis jako przyczyna nieważności małżeństwa $w$ świetle nowszej jurysprudencji rotalnej, dz. cyt., s. 113.

${ }^{82}$ Por. L. Świto, Exclusio boni prolis..., dz. cyt., s. 95.

${ }^{83}$ Dec. c. Pinna z 26.02.1965 r., SRRDec. 57 (1965), s. 232: „Ad trutinam causa simulandi, quae de se nec probationem nec praesumptionem suppeditat, sed illustrat vim actus positivi ceterum probati, quatenus, eodem admissio, facile concedi potest radicalem fuisse eo quod radicalis seu proportinata cum ipsius iuris exclusione fuit causa quae ad actum positivum duxit. Comparanda est insuper cum causa contrahendi ut dignosci valeat utra praevaluerit".

${ }^{84}$ Por. dec. c. Serrano Ruiz Z 26.03.1993, RRDec. 85 (1993), s. 266.

${ }^{85}$ Por. dec. c. Serrano Ruiz z 26.03.1993, RRDec. 85 (1993), s. 262.

${ }^{86}$ Por. dec. c. Stankiewicz z 29.05.1992, RRDec. 84 (1992), s. 306.

${ }^{87}$ Por. dec. c. Canals z 29.05.1963, SRRDec. 55 (1963), s. 397.

${ }^{88}$ Por. dec. c. Stankiewicz Z 29.05.1992, RRDec. 84 (1992), s. 317-319. 
względy ekonomiczne ${ }^{89}$, homoseksualizm ${ }^{90}$, skutek wykluczenia boni sacrament $i^{91}$ i niezrozumienie natury małżeństwa ${ }^{92}$.

Oprócz wymienionych wyżej przyczyn symulacji w stosunku do dobra potomstwa sędzia dokonujący oceny zobowiązany jest do uwzględnienia wszystkich elementów i okoliczności sprawy (circumstantiae). Zalicza się do nich wszystkie fakty mające związek z małżeństwem, którego ważność została zaskarżona ${ }^{93}$. Okoliczności powinny być takie, aby nie pozostawiały wątpliwości co do woli symulanta, tzn. iż zawarł on małżeństwo, ale tylko dlatego, że wykluczył bonum prolis. Jeśli są wiarygodne, pozwalają sędziemu na wyrobienie sobie ostatecznego zdania w rozstrzygnięciu sprawy ${ }^{94}$. Chodzi o to, aby przy ich pomocy sędzia jednoznacznie orzekł, czy w momencie wyrażania konsensusu małżeńskiego wykluczono ipsum ius, czy tylko usus iuris. Wskazane okoliczności dzielą się na trzy grupy: okoliczności przedślubne (np. niechęć do dzieci, liberalne podejście do seksualności ${ }^{95}$ ), okoliczności towarzyszące zawieraniu małżeństwa (np. przebieg i miejsce uroczystości, zadowolenie kontrahentó ${ }^{96}$, stawianie warunków) i okoliczności poślubne (np. uporczywe stosowanie środków antykoncepcyjnych ${ }^{97}$, odmowa współżycia naturalnego, aborcja).

Na zakończenie warto jeszcze dodać, że szczególną trudność w ocenie sędziowskiej sprawia okoliczność wydania na świat potomstwa. Trzeba

${ }^{89}$ Por. dec. c. Di Felice z 22.07.1970, SRRDec. 62 (1970), s. 816.

${ }^{90}$ Por. dec. c. Anne z 16.07.1963, SRRDec. 55 (1963), s. 624.

${ }^{91}$ Por. dec. c. Stankiewicz z 29.05.1992, RRDec. 84 (1992), s. 320; por. R. Wierzchanowski, „Bonum coniugum” $i$ „bonum prolis” jako przedmiot symulacji zgody małżeńskiej (kan. 1101 $\$ 2$ KPK), ,Teologiczne Studia Siedleckie” 10 (2013), s. 78.

${ }_{92}$ Por. dec. c. Bruno Z 12.03.1993, RRDec. 85 (1993), s. 148; dec. c. Stankiewicz Z 29.05.1992, RRDec. 84 (1992), s. 320: „Immo actricis parentes potissimum a filia ante nuptias cognoscere poterant proposita simulatoria conventi, profitentis liberas uniones absque fine procreativo". Por. P. Bianchi, L'esclusione della prole nella giurisprudenza..., dz. cyt., s. 133-136; 138-140; por. T. Pawluk, Wiedza nupturientów w świetle wymogów kanonicznych i postulatów duszpasterskich, [w:] Przymierze matżeńskie, dz. cyt., s. 53-54; W. Góralski, Niezdolność do podjęcia istotnych obowiązków matżeńskich, [w:] Przymierze matżeńskie, dz. cyt., s. 40-43; W. Góralski, Exclusio boni prolis jako przyczyna nieważności małżeństwa w świetle nowszej jurysprudencji rotalnej, dz. cyt., s. 115-116.

${ }^{93}$ Por. kan. 1674 KPK.

${ }^{94}$ Por. dec. c. Stankiewicz z 17.12.1993, RRDec. 85 (1993), s. 783.

95 Por. dec. c. Bruno Z 12.03.1993, RRDec. 85 (1993), s. 146-147.

${ }_{96}$ Por. dec. c. Serrano Ruiz z 26.03.1993, RRDec. 85 (1993), s. 262.

97 Por. dec. c. Civili z 9.12.1992, RRDec. 84 (1992), s. 639. 
powiedzieć, iż jakkolwiek są to rzadkie przypadki, to jednak nie wykluczają one możliwości udowodnienia nieważności małżeństwa $\mathrm{z}$ tytułu wykluczenia potomstwa. W orzeczeniach Roty Rzymskiej zdarzały się wyroki stwierdzające nieważność małżeństwa mimo posiadania dzieci. Dzieje się tak, gdyż należy odróżnić factum prolis od intentio prolis ${ }^{98}$. W takim przypadku należy także ocenić stosunek rodzica do dziecka i jego wychowania.

\section{Najczęstsze przyczyny exclusio boni prolis}

Analiza akt Sądu Diecezjalnego w Tarnowie pozwala stwierdzić, iż zdecydowana większość przyczyn wykluczenia dobra potomstwa wskazana $\mathrm{w}$ orzeczeniach rotalnych znajduje swoje odzwierciedlenie także w wyrokach sądu tarnowskiego. Przyczyny te umownie można podzielić na następujące kategorie:

- praca i kariera ${ }^{99}$,

- egoizm i wygodnictwo ${ }^{100}$,

- nieodpowiedzialność i niedojrzałość psychiczna ${ }^{101}$,

- lęk przed porodem i wychowaniem potomstwa ${ }^{102}$,

- brak miłości i awersja do współmałżonka ${ }^{103}$,

- zdegradowanie moralne $\mathrm{e}^{104}$.

Na określenie źródła symulacji pozwalają sędziemu przede wszystkim zeznania stron i świadków oraz ujawnione okoliczności przed zawarcie małżeństwa i po nim. Nadto orzekający musi upewnić się, że owa

${ }_{98}$ Por. dec. c. Ewers z 27.01.1965, SRRDec. 57 (1965), s. 77-78; dec. c. Davino z 21.12.1967, „Monitor Ecclesiasticus” 4 (1969), s. 549: „Ex adverso, posito facto prolis, per se inferendum quod praecesserit intentio prolis, at non necessario, positive enim constare potest prolem illam fortuito et contra coniugum intentionum advenisse in matrimonio".

99 Por. dec. c. Kostrzewa z 31.12.2008, s. 97-110; dec. c. Gabryel z 11.10.1994, s. 88-96; dec. c. Gajda Z 12.08.1993, s. 82-89; dec. c. Gajda z 30.04.2003, s. 148-164; dec. c. Gabryel Z 24.02.2010, s. 79-90.

${ }^{100}$ Por. dec. c. Gajda 4.09.1993, s. 83-89; dec. c. Gajda z 25.10.1994, s. 88-97; dec. c. Rozkrut z 12.10.2000, s. 53-62; dec. c. Kostrzewa z 26.04.2002, s. 94-103.

${ }^{101}$ Por. dec. c. Gajda z 28.08.1991, s. 95-101; dec. c. Gajda z 7.07.1992, s. 79-85; dec. c. Tokarz z 4.11.1997, s. 104-112.

${ }^{102}$ Por. dec. c. Tokarz z 4.11.1997, s. 104-112; dec. c. Gajda 8.01.1995, s. 135-143.

${ }^{103}$ Por. dec. c. Gajda z 12.08.1993, s. 82-89; dec. c. Kostrzewa 4.04.2008, s. 77-88.

${ }^{104}$ Por. dec. c. Kostrzewa z 26.04.2002, s. 94-103. 
causa simulationis $\mathrm{w}$ rozumieniu symulanta uchodziła za poważną i realną - a więc miała decydujące znaczenie ${ }^{105}$. Jeśli więc przyczyna jest proporcjonalnie poważna (przynajmniej w ocenie kontrahenta), a także znacząca i trwała, to stanowi doniosły dowód w sprawie. Audytorzy Roty Rzymskiej są zgodni, iż należy dokładnie zbadać causam simulandi, gdyż człowiek nigdy nie działa bez odpowiedniej przyczyny. A ponieważ $\mathrm{w}$ wykluczeniu dobra potomstwa idzie o poważny i istotny element małżeństwa, przyczyna tego wykluczenia też nie może być błaha ${ }^{106}$. Określając przyczynę, należy także zbadać podejście domniemanego symulanta do życia i do małżeństwa jako takiego. Jeśli ktoś od samego początku trwania małżeństwa i niezależnie od istniejących okoliczności wykluczał pożycie cielesne (copula carnalis), a zwłaszcza płodne akty małżeńskie, to jest wysoko prawdopodobne, iż implicite wykluczył dobro potomstwa ze swego małżeństwa.

\section{I. Praca i kariera}

Pierwsza $\mathrm{z}$ wymienionych przyczyn dobrze widoczna jest w wyroku c. Kostrzewa z 31.12.2008, gdzie ponens stwierdza, iż pozwana poprzez wielorakie czynności zmierzające do uniknięcia poczęcia dziecka wykluczyła w sposób wyraźny, tak przed ślubem, jak i po nim, akty małżeńskie per se aptos ad prolis generationem ${ }^{107}$. A zatem nie było to odłożenie posiadania potomstwa w czasie, spowodowane chęcią studiowania, lecz wykluczenie potomstwa per se, skutkujące wadliwością umowy małżeńskiej. W innym przypadku mielibyśmy do czynienia jedynie $\mathrm{z}$ nadużyciem prawa, a sam konsensus nie doznałby uszczerbku prawnego, według rzymskiej zasady: Rite contractum matrimonium ex post vitiari non potest $t^{108}$. Tymczasem orzekający nie mieli wątpliwości, iż w tym przypadku zarzucone zostało prawo - obowiązek płodnych aktów małżeńskich, jak

\footnotetext{
${ }^{105}$ Por. dec. c. Pinna z 26.02.1965, SRRDec. 57 (1965), s. 232.

${ }^{106}$ Por. W. Góralski, Wykluczenie bonum prolis w opublikowanych wyrokach Roty Rzymskiej $z 2002$ r., „Ius Matrimoniale” 18 (2013), s. 95-96.

${ }^{107}$ Por. W. Góralski, Wykluczenie bonum prolis w opublikowanych wyrokach..., dz. cyt., S. 98.

${ }^{108}$ Por. W. Góralski, Wykluczenie bonum prolis w opublikowanych wyrokach..., dz. cyt., s. 97.
} 
również prawo - obowiązek nieprzeszkadzania prokreacji ${ }^{109}$. Zaistniała simulatio partialis (poprzez pozytywny akt woli ${ }^{110}$ ) nie tylko spowodowała nieważność samego małżeństwa, lecz także sprawiła, iż niemożliwym stało się zbudowanie prawdziwej wspólnoty życia między kontrahentami. Tym samym na pytanie zadane w Dekrecie zawiązania sporu: Czy małżeństwo $\mathrm{N}$ i $\mathrm{N} \mathrm{z}$ tytułu pozornej zgody - wykluczenie potomstwa (kan. $1101 \$ 2$ KPK) po stronie pozwanej kobiety zostało zawarte nieważnie? - udzielono odpowiedzi twierdzącej ${ }^{111}$. Podobną, dość jasną sytuację, znajdujemy w wyroku c. Gabryel z 11.10.1994 ${ }^{112}$.

\subsection{Egoizm i wygodnictwo}

Drugą najczęściej spotykaną przyczyną symulacji parcjalnej są egoizm i wygodnictwo. Tymczasem ustawodawca kościelny w kan. 1135 KPK stwierdza wyraźnie, że „oboje małżonkowie mają jednakowe obowiązki i prawa w tym, co dotyczy wspólnoty życia małżeńskiego". Ta zaś wspólnota, jak stwierdza kan. 1055 aktualnego kodeksu, skierowana jest ze swej natury do dobra małżonków oraz równorzędnie do zrodzenia i wychowania potomstwa. Ważność tych zadań potwierdzają także dokumenty Soboru Watykańskiego II, jak chociażby konstytucja Gaudium et spes ${ }^{113}$ i deklaracje: Dignitatis humanae ${ }^{114}$ oraz Gravissimum educationis ${ }^{115}$.

${ }^{109}$ Por. P. J. Viladrich, Konsens małżeński. Sposoby prawnej oceny i interpretacji $w$ kanonicznych procesach o stwierdzenie nieważności małżeństwa, tłum. S. Świaczny, Warszawa 2002, s. 304-317; KDK 48.

${ }^{110}$ Por. KPK kan. $1101 \S 2$.

${ }^{111}$ Natomiast $\mathrm{w}$ procesie tym nie udowodniono nieważności małżeństwa $\mathrm{z}$ tytułu kan. 1095, n. 2 KPK. Dnia 10.02.2010, trybunał II instancji zatwierdził dekretem wyrok stwierdzający nieważność małżeństwa z tytułu wykluczenia dobra potomstwa wydany przez I instancję.

${ }_{112}$ „Przed ślubem wyraźnie i jasno postanowiłam pozwanemu kwestię, że pobierzemy się, ale po ślubie nie będziemy mieć potomstwa. On zgadzał się na to. Mówiłam swej przyjaciólce NN, że nie planuję potomstwa. I przed ślubem i w czasie zawierania małżeństwa świadomie i pozytywnym aktem woli wykluczyłam potomstwo ze swego małżeństwa. Tej decyzji nigdy nie odwołałam ani przed ślubem, ani w czasie zawierania małżeństwa, ani po jego zawarciu. [...] Chciałam zrealizować się jako naukowiec historyk. Nigdy nie żyliśmy w okresach płodnych, abym nie zaszła w ciążęe. Dec. c. Gabryel z 11.10.1994, s. 90.

${ }^{113}$ KDK 5O-52.

${ }^{114} \mathrm{DH} 5$.

${ }^{115}$ DWCH 3. 
Ważną wskazówkę w tej materii odnajdujemy także w kan. 1151 KPK, który zobowiązuje małżonków do zachowania pożycia małżeńskiego. Nadto Piotr Majer w odniesieniu do istotnych zadań wynikających z ważnie zawartego małżeństwa dodaje jeszcze pięć zasad - swego rodzaju wytycznych życia małżeńskiego. Według nich małżonkowie winni: 1) dochować sobie wierności, 2) dążyć do wzajemnego doskonalenia cielesnego, 3) dążyć do wzajemnego doskonalenia duchowego, 4) żyć razem, 5) dążyć do osiągnięcia materialnego i duchowego dobra posiadanych dzieci ${ }^{116}$.

Przykładem wykluczenia dobra potomstwa, którego motywem były egoizm i wygodnictwo, jest wyrok c. Gajda z 4.09.1993. W części de iure ponens przypomina, iż małżonkowie powinni mieć intencję przyjęcia dzieci (intentio prolis) ze związku, który z sobą zawierają. Wykluczenie tego elementu jest istotnym brakiem, wadą zgody małżeńskiej powodującą jej pełną nieważność. Ponens zaznacza, iż w procesie nie wystarczy udowodnić sam fakt braku potomstwa czy fakt unikania spłodzenia go, lecz trzeba udowodnić wykluczenie uprawnienia. Inaczej mówiąc, z moralną pewnością powinno się wykazać, że prawo do ciała (w odniesieniu do płodnych aktów małżeńskich) zostało wykluczone pozytywnym aktem woli, było wykluczone. Jeżeli kontrahent wykluczył potomstwo tylko na pewien czas, ale wykluczenie to obejmuje samo uprawnienie, małżeństwo jest nieważnie zawarte, gdyż postanowienie to jest przeciwne całkowitemu przekazaniu prawa do ciała ${ }^{117}$. Temu uzasadnieniu prawnemu odpowiada stan faktyczny powodujący w opisanym przypadku nieważność umowy małżeńskiej.

W trakcie procesu ustalono, że pozwany, wychowując się w dobrobycie, nie nauczył się samodzielności życiowej. Zebrany materiał dowodowy pozwala stwierdzić, że był człowiekiem wygodnym, samotnikiem, nieprzywykłym do ponoszenia trudów i niewygód życia rodzinnego. Nadto przez cały czas stosował środki zapobiegawcze, by nie doszło do niepożądanej ciąży. Ponieważ powódka nie miała zamiaru czekać trzy lata na potomstwo, a jej prośby o potomstwo zostały odrzucone, użyła podstępu. Jego owocem było zajście w ciążę. Reakcja pozwanego była gwałtowna i konsekwentna: okazywał swoją złość, gniew i oburzenie. Zarzucał żonie zdradę małżeńską, a w końcu wniósł do sądu skargę o rozwód i zaprzeczenie

\footnotetext{
${ }^{116}$ Por. Kodeks Prawa Kanonicznego..., dz. cyt., s. 863-864.

${ }^{117}$ Por. dec. c. Gajda z 4.09.1993, s. 84-85; por. dec. c. Tokarz z 9.10.1987, s. 101-102.
} 
ojcostwa ${ }^{118}$. Przytoczone fakty dobitnie przekonały sędziów, iż pozwany nie tylko wykluczył potomstwo, lecz także prawo do ciała w odniesieniu do płodnych aktów małżeńskich ${ }^{119}$. Analizując nauczanie św. Augustyna, można powiedzieć, iż małżeństwo traktował instrumentalnie - jako miejsce realizacji pożądliwości ${ }^{120}$. W tym przypadku mamy do czynienia nie tylko z wykluczeniem (z nieprzekazaniem) prawa do płodnych aktów, lecz również z niespełnieniem prawa - obowiązku nieprzeszkadzania skutkom pożycia małżeńskiego. Chodzi tu o dobro potomstwa już poczętego, wobec którego pozwany domagał się podjęcia aktów destrukcyjnych. W sprawie tej ujawnia się jeszcze zależność między bonum coniugum a bonum prolis. Konsekwentne trwanie pozwanego w powziętym postanowieniu nieposiadania potomstwa zniszczyło późniejszą wspólnotę. Dzieje się tak, gdyż małżeństwo jest „sakramentem społecznym, to znaczy sakramentem, który jest przyjmowany dla drugiego (dla małżonka) i dla założenia rodziny" ${ }^{121}$. Z podobną sytuacją mamy do czynienia w wyroku c. Rozkrut z 12.10.2000.

\subsection{Nieodpowiedzialność i niedojrzałość psychiczna}

Akta spraw procesów małżeńskich pokazują, iż źródłem wykluczenia dobra potomstwa może być nieodpowiedzialność i niedojrzałość psychiczna. Nie chodzi tu o taki stopień niedojrzałości, o którym mówi kan. 1095, $3^{\circ} \mathrm{KPK}^{122}$, lecz o taką niedojrzałość, która wzmacniana czynnikami

${ }^{118}$ Por. Por. dec. c. Gajda z 4.09.1993, s. 84-85; por. dec. c. Tokarz z 9.10.1987, s. 101-102.

${ }^{119}$ Wyrok stwierdzający nieważność tego małżeństwa został zatwierdzony przez II instancję 22.12.1993.

${ }^{120}$ Św. Augustyn, De bono coniugali, PL 40, s. 394; św. Augustyn, De Genesi contra Manichaeos, PL 34, s. 204.

${ }^{121} \mathrm{~W}$. Góralski, Wykluczenie bonum prolis w opublikowanych wyrokach..., dz. cyt., s. 79; por. także: M. Czapla, Pojęcie matrimonium foedus w kan. $1055 \$ 1$ kpk, „Ius Matrimoniale” 5 (2000), s. 32-36.

${ }^{122} \mathrm{Za}$ niezdolność konsensualną, a tym samym przyczynę nieważności małżeństwa prawodawca uznaje złożony zbiór anomalii psychicznych, wśród których wyróżniają się zaburzenia psychoseksualne i psychopatyczne. Dotykają one samej struktury podmiotu (kontrahenta), niekoniecznie pozbawiając go wystarczającego używania rozumu, ani też bezpośrednio i wyraźnie rozeznania oceniającego - czyli rozpoznającego przedmiot konsensusu. Jednakże powodują w nim psychopatologiczną niemożliwość wzięcia na siebie istotnych obowiązków małżeńskich. Naturalnie ową incapacitas assumendi należy odróż- 
zewnętrznymi, skłania działający podmiot do podjęcia decyzji o wykluczeniu jednego $\mathrm{z}$ dóbr małżeńskich - w tym wypadku dobra potomstwa. Tak więc owa niedojrzałość i nieodpowiedzialność nie są same w sobie przyczyną nieważności małżeństwa, lecz zalążkiem, z którego wypływają decyzje pozytywnego aktu woli skutkującego już wadliwością konsensusu małżeńskiego. Oczywiście rozróżnienie to nie przekreśla możliwości prowadzenia spraw z tytułu wspomnianego kan. $1095^{123}$. Przykładem tego rodzaju przyczyny wykluczenia potomstwa jest wyrok c. Tokarz z dnia 4.11.1997, w którym czytamy, że pozwana od samego początku pożycia, tj. jeszcze przed slubem jasno deklarowała, że nie wyobraża sobie posiadania dziecka. Swoją wolę okazywała wielokrotnie, chociaż powód nie traktował jej słów dosłownie. Taka postawa kobiety sprawiła, że powód usiłował doprowadzić do poczęcia dziecka przy wyraźnym sprzeciwie pozwanej $j^{124}$.

Na pewną analizę zasługuje tu także postawa powoda, a właściwie jego czynności zmierzające do posiadania dziecka. W zeznaniach jest mowa o akcie małżeńskim dokonanym siłą, który z jednej strony ukazuje mocne pragnienie bycia ojcem, ale $\mathrm{z}$ drugiej odsłania pewien nieład moralny i błędne rozumienie małżeństwa jako instytucji, która niejako „Z automatu” wydaje potomstwo. Nie ma bowiem aktu ludzkiego, gdy nie ma wolności. Dziecko będące dobrem małżeńskim i owocem wzajemnej miłości nigdy nie może być wynikiem czynu zabronionego, który dodatkowo sprzeciwia się obrazowi małżeństwa chrześcijańskiego. Ius ad procreationem nie jest równoważne $\mathrm{z}$ ius ad prolem. Przypomina o tym

nić od zwykłej trudności życiowej w wypełnieniu jakiegoś istotnego obowiązku małżeńskiego. Zwrócił na to uwagę Jan Paweł II w przemówieniu do Roty Rzymskiej 5 lutego 1987 roku, stwierdzając, że o autentycznej niezdolności można mówić jedynie wtedy, gdy zawierający małżeństwo dotknięty jest prawdziwą anomalią, niweczącą całkowicie zdolność do rozumowania lub/ i chcenia. Por. Kodeks Prawa Kanonicznego. Komentarz..., dz. cyt., Kraków 2011, s. 815; W. Góralski, Kościelne prawo matżeńskie, Warszawa 2006, s. 131-132.

${ }^{123}$ Kan. 1095 KPK stwierdza: „Niezdolni do zawarcia małżeństwa są ci, którzy: $1^{\circ}$ są pozbawieni wystarczającego używania rozumu; $2^{\circ}$ mają poważny brak rozeznania oceniającego co do istotnych praw i obowiązków małżeńskich wzajemnie przekazywanych i przyjmowanych; $3^{\circ} \mathrm{z}$ przyczyn natury psychicznej nie są zdolni podjąć istotnych obowiązków małżeńskich".

${ }^{124}$ Dec. c. Tokarz z dnia 4.11.1997, s. 111. Wyrok zakończył się stwierdzeniem nieważności małżeństwa i został potwierdzony dekretem Sądu II instancji z dnia 18.03.1998. Por. także: dec. c. Gajda z 30.04.2003, s. 163-164. 
instrukcja Donum vitae, dając do zrozumienia, że prawo do uprzedmiotowienia dziecka sprzeciwiałoby się jego godności i naturze ${ }^{125}$. Jako dar i owoc miłości małżeńskiej jest żywym świadectwem dobrowolnego oddania się małżonków. Chociaż małżeństwo udziela małżonkom, w sposób obiektywny i niezbywalny, wyłącznego prawa stania się ojcem i matką, to jednak nie daje absolutnego prawa do posiadania dziecka. Chodzi zatem o osobiste prawo do prokreacji małżonków za pośrednictwem aktu osobowej (ludzkiej) miłości małżeńskiej, który uważany jest w nauczaniu Kościoła za jedyne godne miejsce ludzkiej prokreacji ${ }^{126}$.

\subsection{Lęk przed porodem i wychowaniem potomstwa}

Ten rodzaj przyczyny powodujący symulację częściową został już wyżej pośrednio omówiony. Lęk przed porodem i wychowaniem potomstwa bardzo często łączy się z niezdolnością do zawarcia małżeństwa z przyczyn natury psychicznej, tzn. towarzyszy różnego rodzaju nerwicom lękowym, obsesyjnej fobii, osobowości socjopatycznej czy depresji ${ }^{127}$. Dla zobrazowania tego rodzaju przyczyny wykluczenia potomstwa wybrałem sprawę, w której lęk nie ma natury czysto psychicznej, lecz wynika z już posiadanego potomstwa, wieku i "nie najlepszego" prowadzenia się kontrahenta ${ }^{128}$. Co więcej, owo wykluczenie boni prolis ma zupełnie inny charakter niż w sprawach wyżej przedstawionych. Dla stron potomstwo nie było czymś abstrakcyjnym, gdyż zarówno powódka, jak i pozwany, będąc wdowcami, mieli już dzieci z poprzedniego małżeństwa. W dniu zawarcia nowego związku strony miały po 48 lat. W takich okolicznościach powódka stanowczo wykluczyła możliwość posiadania dzieci z pozwanym. Wolę taką wyrażała zarówno przed ślubem, jak i po nim. W tym celu stosowała zarówno dobrze jej znane naturalne metody kontroli płodności, jak i inne sposoby - najczęściej mechaniczne zabezpieczenia, które sama nabywała i pilnie stosowała. Z akt sprawy wynika, że żona nie oddała mężowi prawa do ciała w odniesieniu do aktów, z których mogłoby nastąpić

\footnotetext{
${ }^{125}$ Por. DV 8.

${ }^{126}$ Por. W. Góralski, Wykluczenie bonum prolis w opublikowanych wyrokach..., dz. cyt., s. 80 ; KKK 2376.

${ }^{127}$ Por. W. Góralski, Kościelne prawo małżeńskie, dz. cyt., s. 134.

${ }^{128}$ Por. dec. c. Kostrzewa z 8.01.1995, s. 141-142.
} 
poczęcie. Odmawiała mu wprost tego prawa-obowiązku, gdy się o nie upominał. Podjętą decyzję tłumaczyła obawą o własne zdrowie i kondycję ewentualnego potomstwa, lękiem o przyszłość, starszym wiekiem oraz skłonnościami pozwanego do nadużywania alkoholu. W jej mniemaniu pozwany nie czuł się odpowiedzialny za dom, żonę i dzieci. Te opinie miały pełne uzasadnienie we wcześniejszym związku. Zeznania stron $\mathrm{w}$ sprawie wykluczenia dobra potomstwa i prawa do ciała były niemal całkowicie zgodne i poparte zeznaniami trzech wiarygodnych świadków, $\mathrm{w}$ tym jednego świadka $\mathrm{z}$ okresu przedślubnego ${ }^{129}$. W wydanym wyroku Sąd Diecezjalny w Tarnowie stwierdził nieważność zawartego małżeństwa z dwóch tytułów: $\mathrm{z}$ tytułu wykluczenia dobra potomstwa oraz z tytułu niezdolności do podjęcia i wypełnienia istotnych obowiązków małżeńskich po stronie pozwanego ${ }^{130}$.

\subsection{Brak miłości i awersja do współmałżonka}

Trudno wyobrazić sobie sytuację, w której nupturienci zawierający związek małżeński nie są powodowani miłością i wzajemnym zauroczeniem. To przecież miłość - ta cielesna i duchowa - buduje wspólnotę życia, pozwala wytrwać w sytuacjach napięcia i nieporozumień. Wreszcie ta miłość małżeńska znajduje swoje szczytowe uwyraźnienie we wspólnym potomstwie ${ }^{131}$. Akta sądowe pokazują jednak, iż istnieją przypadki par, w których występuje nie tylko brak miłości, ale nawet awersja do kontrahenta.

$\mathrm{W}$ tym przykładzie mamy do czynienia $\mathrm{z}$ dopełnieniem małżeństwa non humano modo - a więc właściwie $\mathrm{z}$ brakiem jego dopełnienia ${ }^{132}$. Tymczasem według kan. $1057 \$ 2 \mathrm{KPK}^{133}$ wzajemne oddanie się i przekazanie małżonków dokonujące się w akcie zgody małżeńskiej obejmuje m.in. sferę seksualną, w której wymownie znajduje swój wyraz jedność i miłość

\footnotetext{
${ }^{129}$ Dec. c. Kostrzewa z 8.01.1995, s. 142.

${ }^{130}$ Dekret Sądu II instancji zatwierdzający niniejszy wyrok wydano 6.09.1995.

${ }^{131}$ Por. K. Wojtyła, Miłość i odpowiedzialność, Lublin 1986, s. 42; KKK 2366; Jan Paweł II, adhort. apost. Familiaris consortio, 50, 55.

${ }^{132}$ Dec. c. Kostrzewa z 4.04.2008, s. 86-87.

${ }^{133}$ Kan. $1057 \$ 2$ KPK stwierdza: „Zgoda małżeńska jest aktem woli, którym mężczyzna i kobieta w nieodwołalnym przymierzu wzajemnie się sobie oddają i przyjmują w celu stworzenia małżeństwa”.
} 
małżeńska ${ }^{134}$. Ta zaś miłość manifestuje się i dopełnia w szczególny sposób właściwym aktem małżeńskim. Akty, „przez które małżonkowie jednoczą się w sposób intymny i czysty, są uczciwe i godne; a jeśli spełniane są prawdziwie po ludzku (modo vere humano), są oznaką i podtrzymaniem wzajemnego oddania się"135. To one urzeczywistniają podwójny cel małżeństwa: dobro małżonków oraz przekazywanie życia ${ }^{136}$. W tym miejscu należy także przywołać kan. $1061 \$ 1 \mathrm{KPK}, \mathrm{w}$ którym prawodawca określił pojęcie małżeństwa zawartego i dopełnionego (ratum et consummatum): jest nim takie małżeństwo, w którym „małżonkowie podjęli w sposób ludzki akt małżeński przez się zdolny do zrodzenia potomstwa". $\mathrm{W}$ tej definicji należy uwypuklić zwroty humano modo i per se aptum ad prolis generationem. Widać zatem, że spełnianie takiego rodzaju aktów jest istotnym obowiązkiem małżeńskim, w którym urzeczywistniają się komplementarnie obydwa cele małżeństwa. Obowiązek ten wypływa ex iustitia, gdyż rodzi się z istoty małżeństwa jako ,jedno ciało”, czyli "jedność w naturalności”"137. Spełnianie aktów na sposób ludzki (humano modo), a więc świadomie i dobrowolnie, wskazuje na realizację przede wszystkim dobra małżonków (bonum coniugum). Natomiast spełnianie ich jako przez się zdolnych do zrodzenia potomstwa (czyli otwartych na prokreację) wskazuje na realizację przede wszystkim bonum prolis ${ }^{138}$. Realizacja aktów małżeńskich pod przymusem (gwałt) lub w nieświadomości (np. pod wpływem alkoholu, upojenia narkotycznego, w stanie nieprzytomności), lub bez udziału nasienia własnego małżonka (a więc pochodzącego ze stosunku spełnionego w sposób nienaturalny) nie spełnia wymagań prawnych, a co za tym idzie nie następuje dopełnienie małżeństwa (matrimonium ratum sed non consummatum). Dzieje się tak, gdyż copula matrimonialis perfecta oprócz elementu ściśle biologicznego zawiera element personalny, tj. całe bogactwo osoby ludzkiej; a przymierze małżeńskie jest takiej natury, że jego przedmiot powinien wynikać ex ipsa rei natura ${ }^{139}$. Podobnie więc prawa-obowiązku spełnie-

${ }^{134}$ Por. W. Góralski, Dobro małżonków a istotne obowiązki małżeńskie, Warszawa 2010, s. 111.

${ }^{135}$ KDK 49.

${ }^{136}$ Por. KKK 2363.

${ }^{137}$ Por. W. Góralski, Dobro małżonków a istotne obowiązki małżeńskie, dz. cyt., s. 112.

${ }^{138}$ W. Góralski, Dobro małżonków a istotne obowiązki małżeńskie, dz. cyt., s. 112.

${ }^{139}$ Por. W. Góralski, Dobro małżonków a istotne obowiązki małżeńskie, dz. cyt., s. 114. 
nia aktów małżeńskich humano modo nie może podjąć osoba orientacji homoseksualnej.

Innym przykładem, w którym powodem wykluczenia potomstwa był brak miłości do współmałżonka, jest wyrok c. Gajda z $12.08 .1993^{140}$. W wyroku sąd orzekł nieważność małżeństwa z tytułu symulacji częściowej po stronie pozwanej ${ }^{141}$.

\subsection{Zdegradowanie moralne}

Kanon $1096 \$ 1$ KPK wymaga od nupturientów pewnej podstawowej wiedzy ogólnej, że małżeństwo jest trwałym związkiem mężczyzny i kobiety oraz że jest skierowane do zrodzenia potomstwa przez jakieś współdziałanie seksualne (cooperatione aliqua sexuali). Paragraf 2 tegoż kanonu zawiera praesumptio iuris, według którego po osiągnięciu dojrzałości nie domniemywa się takiej ignorancji. Jak pokazują akta Sądu Diecezjalnego w Tarnowie, można doskonale orientować się, czym jest małżeństwo i ku czemu jest skierowane, a jednocześnie na skutek zarzucenia życia religijnego i degradacji moralnej wykluczyć bonum prolis ze swego małżeństwa. W takiej sytuacji ma miejsce nie błąd, o którym traktuje kan. $1099 \mathrm{KPK}^{142}$, lecz symulacja zakorzeniona w złym prowadzeniu się i zanegowaniu elementarnych norm moralnych. Przykładem tego rodzaju przyczyny symulacji jest wyrok z dnia 26.04.2002. Jest on o tyle interesujący, że obrazuje pewną zależność między wykluczeniem dobra potomstwa a wykluczeniem nierozerwalności małżeństwa. W cytowanym fragmencie ponens stwierdził, że „pozwany wolał ją (żonę) zostawić, niż mieć z nią dzieci”. Doświadczenie pokazuje, że bardzo często ten, kto nosi się z zamiarem odejścia od małżonka i zerwania wspólnoty małżeńskiej, żywi również postanowienie uczynienia wszystkiego, co w jego mocy, by nie doszło do poczęcia potomstwa. Powód jest tu oczywisty: chodzi o to, by po rozejściu się nie obciążać siebie poważnym obowiązkiem utrzymania i wychowania dziecka ${ }^{143}$. Jeśli więc weźmiemy pod uwagę

${ }^{140}$ Dec. c. Gajda z 12.08.1993, s. 85 i 89.

${ }^{141}$ Dekret Sądu II instancji potwierdzający wyrok Sądu I instancji wydano 20.10.1993.

${ }^{142}$ Kan. 1099 KPK stwierdza: „Błąd co do jedności lub nierozerwalności albo sakramentalnej godności małżeństwa nie narusza zgody małżeńskiej, chyba że determinuje wolę".

${ }^{143}$ Por. dec. c. Di Felice z 29.03.1969, sRRDec. 61 (1969), s. 530. 
rozwiązły styl życia pozwanego, jego stosunek do powódki i burzliwy obraz pożycia małżeńskiego, to możemy stwierdzić $\mathrm{z}$ dużą dozą pewności, że w tym przypadku exclusio boni prolis należy odczytywać jako konsekwencję wcześniejszego exclusio boni sacramenti. Naturalnie mogło być też tak, iż obydwa akty, wykluczające zarówno dobro potomstwa, jak i nierozerwalność małżeństwa, zostały podjęte równocześnie.

\section{Wpływ zeznań stron i świadków na orzeczenia sądowe}

Jak już wspomniano, dowodzenie o nieważności małżeństwa zaskarżonego z tytułu symulacji jest nie lada wyzwaniem dla każdego sędziego. Nie wystarczy bowiem, jak stwierdza art. $247 \$ 2$ Dignitas connubii, zebrać wystarczającą liczbę dowodów i poszlak, gdyż zawsze wymaga się od sędziego „wykluczenia wszelkiej roztropnej i pozytywnej wątpliwości popełnienia błędu, tak co do stanu prawnego, jak i faktycznego"144. Tylko pewność moralna zaczerpnięta $\mathrm{z}$ faktów, dowodów i domniemań upoważnia sędziego do wydania decyzji o nieważności małżeństwa ${ }^{145}$. Jan Paweł II w przemówieniu do Roty Rzymskiej 4.02.1980 podkreślał, że owa moralis certitudo de matrimonii nullitate wypływa ex actis et ex proba$t i s^{146}$. Ponieważ $\mathrm{w}$ tym dowodzeniu należy obalić domniemanie prawne wynikające $\mathrm{z}$ kan. $1101 \$ 1 \mathrm{KPK}$ i ponad wszelką wątpliwość udowodnić symulację kontrahenta $\mathrm{w}$ momencie wyrażania zgody małżeńskiej, sędzia musi dokładnie zanalizować akta, mając jednocześnie świadomość, że $\mathrm{w}$ toku trwania instrukcji sprawy coś mogło zostać przeoczone, zapomniane, a nawet naznaczone podstępem lub oszustwem ${ }^{147}$. Przykładem takiej możliwości są wyroki c. Kostrzewa z 9.04.200148 i c. Kantor $\mathrm{Z}$ 15.12.2010 ${ }^{149}$. W pierwszym przypadku ponens stwierdził, iż świadkowie dopuścili się zmowy, aby fałszywie oskarżyć pozwaną. Tylko rzetelność

\footnotetext{
${ }^{144}$ Stolica Apostolska, Instrukcja procesowa Dignitas connubii, wyd. pol. [dalej: DC], Sandomierz 2007, art. $247 \$ 2$.

${ }^{145}$ Por. KPK kann. 1608, 1060; Z. Grocholewski, Pewność moralna jako klucz do lektury norm procesowych, „Ius Matrimoniale” 3 (1998), s. 9-43.

${ }^{146}$ Por. Jan Paweł II, Allocuciones, 4 II 1980, A As 72 (1980), s. 175.

${ }^{147}$ Por. Komentarz do Instrukcji procesowej „Dignitas connubii”, red. T. Rozkrut, Sandomierz 2007, s. 327.

${ }^{148}$ Por. dec. c. Kostrzewa z 9.04.2001, s. 90-96.

${ }^{149}$ Por. dec. c. Kantor Z 15.12.2010, s. 136.
} 
orzekających i skonfrontowanie zeznań z innymi dowodami i okolicznościami uchroniło orzekających przed błędem ${ }^{150}$. Natomiast w drugim postępowaniu odkryto podstęp po stronie powoda, który za wszelką cenę chciał uzyskać dyspensę super rato od małżeństwa niedopełnionego. Jednak w pełni wiarygodne zeznania pozwanej i innych świadków odkryły wcześniejsze zafałszowanie ${ }^{151}$. Tak więc w kwestii oceny dowodów, ich ważności i wiarygodności sędzia jest zobligowany do rzetelności, a nadto do kierowania się swoim sumieniem i do wiernego zachowania przepisów prawa ${ }^{152}$.

W takiej sytuacji rodzi się pytanie o wiarygodność świadków. Przy ocenie ich zeznań sędzia winien kierować się wytycznymi zamieszczonymi w kan. 1572 KPK, jak również w art. 201 i 202 instrukcji Dignitas connubii. Wynika z nich, iż przy ocenie zeznań świadków sędzia winien wziąć pod uwagę uczciwość osoby, źródło wiedzy zeznającego, czas i okoliczności powzięcia wiadomości, jak również spójność zeznań i ich zgodność z innymi dowodami. Nadto badający sprawę ma (w zwyczajnych okolicznościach) świadectwo kwalifikacyjne wystawione przez proboszcza miejsca zamieszkania. W omawianym przypadku orzekający odwołali się także do starej zasady procesowej, według której unus testis, nullus testis ${ }^{153}$. A zatem zastosowano art. 202 Dignitas connubii, który mówi, że zeznanie jednego świadka nie może być pełnym dowodem, chyba że chodzi o świadka kwalifikowanego, zeznającego o sprawach dokonanych z urzędu, albo okoliczności rzeczy lub osób podpowiadają inaczej ${ }^{154}$. Podobnie rzecz przedstawia się w wyroku c. Gabryel z 18.11.1994, gdzie pozwany próbował wmówić powódce, iż z pewnością nie spełniłaby się $\mathrm{w}$ roli matki i wychowawcy, dlatego ich akty małżeńskie (z jego powodu) zamknięte były na zrodzenie potomstwa. Inaczej mówiąc, źródłem wykluczenia boni prolis miała być niedojrzałość powódki. Sąd jednak nie dał wiary jego zeznaniom, które w znaczący sposób odbiegały od innych zeznań, a nadto ustalił, że wszelkie twierdzenia pozwanego

\footnotetext{
${ }^{150}$ Por. dec. c. Kostrzewa z 9.04.2001, s. 94-95.

${ }^{151}$ Por. dec. c. Kantor Z 15.12.2010, s. 137-139.

${ }^{152}$ Por. DC, art. 161, 201; R. Sobański, Uwagi o funkcji sędziego $w$ procesie o nieważność małżeństwa, „Ius Matrimoniale” 3 (1998), s. 45-59.

${ }^{153}$ Por. Komentarz do Instrukcji procesowej..., dz. cyt., s. 278.

${ }^{154}$ Por. KPK kan. 1573.
} 
o rzekomej symulacji pochodzą z okresu poślubnego, a zatem dotyczą "czasu podejrzanego" ${ }^{155}$.

W ocenie wiarygodności składanych zeznań sędziemu pomaga także rota przysięgi wypowiadana i podpisywana przed przystąpieniem do przesłuchania. Ma ona ogromną wartość, jeżeli składana jest przez osobę pobożną i traktującą na poważnie sprawy wiary ${ }^{156}$.

\section{Wnioski}

1. Wykluczenie dobra potomstwa jest szczególną formą symulacji parcjalnej, która zgodnie z kan. $1101 \$ 2 \mathrm{KPK}$ powoduje nieważność zgody małżeńskiej. Prawna natura tak dokonanej ekskluzji istotnie różni się od warunku, jak i czasowego zawieszenia wykonywania prawa-obowiązku aktów małżeńskich zdolnych do wydania potomstwa.

2. Jak wynika $\mathrm{z}$ akt sądowych, dowodzenie $\mathrm{z}$ tytułu symulacji nasuwa wiele problemów orzekającym, które potęgują się, gdy brak świadków lub gdy ich liczba jest ograniczona albo też wydają się mało wiarygodni (np. na podstawie świadectwa kwalifikacyjnego). Ponadto, jak już wspomniano, sędzia, wydając wyrok za nieważnością małżeństwa, musi osiągnąć w tej kwestii moralną pewność. Niektóre przytoczone wyroki (np. c. Kostrzewa z 9.04.2001) potwierdzają, iż zmowa między świadkami dla obciążenia niewinnej strony jest jak najbardziej możliwa.

3. Do najczęstszych przyczyn wykluczenia boni prolis można zaliczyć: pracę i karierę, egoizm i wygodnictwo, nieodpowiedzialność i niedojrzałość psychiczną, lęk przed porodem i wychowaniem potomstwa, brak miłości i awersję do współmałżonka oraz zdegradowanie moralne.

4. W badanych sprawach sędziowie Trybunału tarnowskiego mieli zazwyczaj do czynienia $z$ tak zwanym wykluczeniem wyraźnym, a więc z sytuacją, gdy kontrahent wprost wykluczył dobro potomstwa. Jeśli zaś chodzi o specyfikę tego wykluczenia, to najczęściej ekskluzja dotyczyła prawa do płodnych aktów małżeńskich. Stąd w wielu sprawach ujawniała się permanentna antykoncepcja (często stosowana już przed ślubem).

\footnotetext{
${ }^{155}$ Por. dec. c. Gabryel z 18.11.1994, s. 129. Natomiast Sąd I instancji orzekł nieważność tego małżeństwa z tytułu kan. 1095, n. 2 i 3, po stronie pozwanego.

${ }^{156}$ Szeroko na ten temat pisze: W. Szafrański, Dowód z przysięgi stron $w$ procesie kanonicznym, „Prawo Kanoniczne” 4 (1962), s. 91-137.
} 
W żadnej sprawie nie ujawniono kontraktu przedślubnego, w którym strony zobowiązałyby się do obopólnego wykluczenia dobra potomstwa.

5. Na uwagę zasługuje fakt, że sędziowie Sądu Diecezjalnego w Tarnowie w bardzo wielu miejscach odwoływali się do orzeczeń Roty Rzymskiej, przywołując fragmenty sentencji wydanych w podobnych sprawach. Nadto w części de iure nierzadko przywoływali uznane autorytety $\mathrm{z}$ kanonicznego prawa małżeńskiego, tak z publikacji zagranicznych, jak i polskich. 